\title{
Gibberellin and spermidine synergistically regulate polyamine metabolism during Rhododendron flower development
}

\section{Qian Xu ( $\sim$ 471017936@qq.com )}

sichuan agricultural university

Huaxiong Li

neijiang City Academy of Agricultural Sciences: Zhangjiakou Academy of Agricultural Sciences

Shiliang Liu

sichuan agricultural universuty

Wenpei Huang

sichuan agricultural university

\section{Xiaolin Xian}

horticulture institute, sichuan academy of agricultural sciences

\section{Qing Li}

TAAAS: Tibet Academy of Agricultural and Animal Husbandry Sciences

\section{Yue Long}

sichuan agricultural university

\section{Rui Chen}

horticulture institute,sichuan academy of agricultural universuty

\section{Zechen Sun}

housing and urban-rural development bureau,guangyuan

\section{Yuanzhi Pan}

Sichuan Agricultural University - Chengdu Campus

\section{Original Research}

Keywords: dynamic variation, exogenous gibberellin, exogenous spermidine, flower senescence, polyamine metabolism

Posted Date: February 3rd, 2021

DOl: https://doi.org/10.21203/rs.3.rs-188291/v1

License: (c) (1) This work is licensed under a Creative Commons Attribution 4.0 International License.

Read Full License 
Version of Record: A version of this preprint was published at Plant Growth Regulation on October 8th, 2021. See the published version at https://doi.org/10.1007/s10725-021-00756-y. 


\section{Abstract}

Polyamines (PAs) are involved in various plants developmental processes, especially in flowering. Their significant influence has been established, but the exact mechanisms by which PAs modulate flowering are not yet understood. To understand the PA metabolism during flowering/senescence in Rhododendron simsii 'Zichendian' plants, exogenous gibberellin $\left(\mathrm{GA}_{3}, 0-2400 \mathrm{mg} \mathrm{L}^{-1}\right)$ and spermidine (Spd, 0-1 mM) were applied separately or in combination during the early stage of flower bud formation. The application of $\mathrm{GA}_{3}$ alone advanced the initial flowering by promoting the free Put $(\mathrm{F})$ fraction and decreasing the $\mathrm{Spd} /$ Put ratio at the squaring stage, whereas Spd alone delayed the initial flowering by increasing the soluble conjugated (C) form, insoluble bound Put (B) fraction and Spd/Put ratio. When $\mathrm{GA}_{3}$ plus Spd was applied, the initial flowering advanced by 2 days. Furthermore, endogenous PA levels as well as the $C$ and $B$ fractions of PAs and key enzymes (diamine oxidase, PA oxidase, arginine decarboxylase, ornithine decarboxylase and Sadenosylmethionine decarboxylase) of PA metabolism increased, while the $\mathrm{Spd} / \mathrm{Spm}$ ratio decreased by $\mathrm{GA}_{3}$ and Spd applications during flowering, resulting in delayed flower senescence. In addition, the structural equation model (SEM) showed that Spd directly participated in PA metabolism, while $\mathrm{GA}_{3}$ regulated flowering by modulating PA metabolism via Spd (c.f. 0.27). Taken together, our study provides comprehensive evidence regarding the clear relationships between $\mathrm{GA}_{3}$, Spd and flowering time, supporting the positive effect of PA metabolism on delaying flower senescence, and helps to provide a thorough understanding of the PA interconversions, biosynthesis and catabolism during flowering and senescence.

\section{Introduction}

Rhododendron simsii Planch. 'Zichendian', one of the most widely used ornamental plants within gardens, is popular due to its abundance of blooms, brightly colored flowers and ease of propagation. Under natural conditions, the 'Zichendian' cultivar blooms from April to May. As this plant is mainly used for attracting tourists and for festivals, the popular market for the sale of this cultivar is restricted to season, which decreases its potential economic benefits. Controlling flowering and delaying senescence are key strategies for planting Rhododendron. Therefore, there have been recent attempts at studying Rhododendron flowering characteristics. Rhododendron flowering and senescence are associated with phytohormone homeostasis, such as GAs, ethylene and polyamines (PAs). Meijon et al. (2011) verified that high levels of free PAs and GA are involved in cell division during the early stage of vegetative growth and flower bud development in Rhododendron. However, low-molecular-weight PA conjugates play a crucial role in floral bud differentiation and maturation processes and correlate with advanced stages of flowering. The use of GA synthesis inhibitors changes the level of PAs and GA, which indicates the significance of GA in Rhododendron development (Meijon et al. 2011). Nevertheless, the role of ethylene in the senescence of Rhododendron is unclear. The expression levels of the ethylene pathway-associated genes MYC2, TIR1, CYCD3, COL-1, and EIN3 peaked at the R. pulchrum flower bud stage, indicating the essential role of ethylene in Rhododendron development (Wang et al. 2018). Rhododendron with dormancy characteristics needs a low temperature to break dormancy and then flower. However, the 
global temperature increase is a potential risk to flowering at the appropriate time, as these plants are highly sensitive to temperature variation and vulnerable to increasing temperature (Yu et al. 2017). The vegetative cycle resumes in summer, exhibiting a simultaneous leaf drop and bud break when the temperature exceeds $10^{\circ} \mathrm{C}$, and the plant system is then unresponsive to any reproductive stimuli (Choudhary et al. 2019). Thus, plant growth regulators are crucial for regulating Rhododendron flowering.

PAs are aliphatic nitrogen-containing compounds found in all living cells. In plants, the most widely distributed PAs are diamine putrescine (Put), tetraamine spermine (Spm), and triamine spermidine (Spd). In addition, cadaverine ( $\mathrm{Cad}$ ) and thermospermine (tSpm) are also found in higher plants (Handa and Mattoo 2010a; Takahashi 2012). Three major PAs exist as soluble conjugated forms or free soluble forms (Evans and Malmberg 1989). Among these, Put is synthesized via the arginine decarboxylase (ADC) pathway and the ornithine decarboxylase (ODC) pathway. Spd and Spm are generated by spermidine synthase (SPDS) and spermine synthase (SPMS), respectively (Ahou et al. 2014; Majumdar et al. 2016; Moschou et al. 2008). PA degradation is catalyzed by diamine oxidase (DAO) and PA oxidase (PAO) (Wang et al. 2019). Moreover, due to the polycationic nature of PAs, they easily interact with negatively charged sites in molecules such as nucleic acids, proteins, and lipids (Masson et al. 2017). Hence, they have diverse functions, especially for plant growth and development. PAs impact in vitro shoot regeneration (Nölke et al. 2010), embryogenesis (Baron and Stasolla 2008), root development (Hummel et al. 2002), pollen tube germination (Sorkheh et al. 2011), flowering (Malmberg and Mcindoo 1983; Qin et al. 2019; Tiburcio et al. 1988), fruit ripening (Fortes and Agudelo-Romero 2018)(Fortes et al., 2018) and leaf and flower senescence (Kaur-Sawhney et al. 1980; Sobieszczuk-Nowicka 2017). Biochemical, transcriptome and proteome approaches have demonstrated that the genomic/proteomic profile of the respective genes/proteins associated with PAs during anthogenesis and flower tissue development is correlated with the endogenous levels of PAs, GA and ethylene during flower development. In addition, previous studies have demonstrated the importance of PAs in the flowering process; for example, Put alone can induce flowering of morning glory in the absence of proper induction conditions (Wada et al. 1994). The accumulation of endogenous hormones in flower buds and in vegetative buds exhibits a specific distribution pattern. However, the dynamic changes in PAs differ depending on treatment and plant species. Bagni and Tassoni (2006) reported that the levels of $F$ and C Spd and Put significantly increased in response to their direct application to carnation petals by spraying, whereas the endogenous PA levels did not vary when the PAs were supplied through the vase water. C Put, Spd and Spm increased steadily throughout the entire flowering time of rosa, and the B Spm and F Spd were found to be the highest during the blooming stage in Rosa damascene and Rosa bourboniana, respectively (Sood and Nagar 2004). Increases in cadaverine and Spd levels in bulbs are a characteristic of flower development in tuberose, and Spd is maintained at a high level during flower development, indicating that Spd participates in flowering and floral development. During carnation senescence, the concentrations of endogenous Spm and Spd do not change with flower senescence, while the concentration of Put rapidly increases (Huang et al. 2004). These studies indicate that the accumulation of PAs is an adaptive mechanism during both flower development and senescence and that PA dynamics are specific and complex. 
Gibberellic acid, a dormancy-breaking chemical, has been used for flower initiation and development (Zhao et al. 2009). PAs are also associated with flower bud dormancy and regulate flowering (Naseri et al. 2019; Rey et al. 1994), both activities that have been characterized as modulating PA metabolism, as evidenced by changes in PA concentrations with exogenous applications of $\mathrm{GA}_{3}$ and Spm during Anthurium senescence (Simões et al. 2018). Dynamic changes in PA levels are considered a response to flower development and senescence. However, the regulation of PA homeostasis is complex and includes biosynthesis, inter-conversion, catabolism and conjugation (Majumdar et al. 2016). The endogenous PAs and $\mathrm{GA}_{3}$ levels are exogenously altered, whereas the level of endogenous PAs could be converted into $\mathrm{GA}_{3}$ quickly, and the enzymes involved in biosynthesis and catabolism are also affected by PA/GA application. Due to the role of $\mathrm{GA}_{3}$ and some PAs in prolonging flowering time, our aim is to characterize PA components and forms (free soluble, insoluble binding and soluble forms) in the flowering and senescence processes of Rhododendron to improve our understanding of the potential relationship between $\mathrm{GA}_{3}$, Spd and flowering. Based on the above background, the following hypotheses were provided in this work: (i) $\mathrm{GA}_{3}$ and Spd regulate PA interconversions during Rhododendron flowering, such as PA components and forms. (ii) $\mathrm{GA}_{3}$ and Spd regulate PA biosynthesis/catabolism by promoting/inhibiting the synthesis and decomposition of PAs and related enzyme activities. (iii) $\mathrm{GA}_{3}$ and Spd regulate PA metabolism, and flower senescence is involved in PA metabolism.

\section{Materials And Methods}

In mid-October, three-year-old cuttings from the same batch of Rhododendron (Rhododendron simsii Planch. 'Zichendian') were supplied by the Institute of Horticulture, Sichuan Academy of Agricultural Sciences. Uniform cuttings (average height of $32.7 \mathrm{~cm}$, average crown size of $26.7 \mathrm{~cm}$, and free of infection) were removed from the plastic bag, and the mature leaves were removed. The roots of the cuttings were then rinsed with clean water and then placed in plastic nutrient bags. With respect to the basic soil properties of the peat soil used, the contents of alkali-hydrolyzable nitrogen, available phosphorus, and quick-release potassium of the peat soil ( $\mathrm{pH}$ of 4.85 , electrical conductivity [EC] of 0.82 $\sim 1.02 \mathrm{dS} \mathrm{m}{ }^{-1}$ ) were $212.46 \mathrm{mg} \cdot \mathrm{L}^{-1}, 97.35 \mathrm{mg} \cdot \mathrm{L}^{-1}$, and $92.64 \mathrm{mg} \cdot \mathrm{L}^{-1}$, respectively, and the organic matter content was $11.2 \mathrm{~g} \cdot \mathrm{L}^{-1}$. The pots were then placed in the greenhouse of the Chengdu Experimental Station of Sichuan Agricultural University (536 m above sea level, $\left.30^{\circ} 71^{\prime} \mathrm{N}, 103^{\circ} 86^{\prime} \mathrm{E}\right)$. All plants were grown with $70-80 \%$ relative air humidity and $25 \pm 3{ }^{\circ} \mathrm{C}$ and $9 \pm 2{ }^{\circ} \mathrm{C}$ average air temperature during the day and night, respectively. Distilled water was supplied at 9:00 a.m. every 3 days (a total of $500 \mathrm{~mL}$ each time), no fertilizer was applied during the experiment, and the plants were treated after their growth had resumed.

The plants ready for treatment were divided into eight groups and treated with (1) distilled water for the control group [control]; (2) $800 \mathrm{mg} \cdot \mathrm{L}^{-1} \mathrm{GA}_{3}$ [T1]; (3) $1600 \mathrm{mg} \cdot \mathrm{L}^{-1} \mathrm{GA}_{3}$ [T2]; (4) $2400 \mathrm{mg} \cdot \mathrm{L}^{-1} \mathrm{GA}_{3}$ [T3]; (5) $0.01 \mathrm{mM}$ Spd [T4]; (6) $0.10 \mathrm{mM}$ Spd [T5]; or (7) $1.00 \mathrm{mM} \mathrm{Spd} \mathrm{[T6];} \mathrm{and} \mathrm{(8)} 2400 \mathrm{mg} \cdot \mathrm{L}^{-1} \mathrm{GA}_{3}+0.10 \mathrm{mM}$ Spd [T7]. The plants were sprayed during the initial stage of flower bud morphological differentiation 
beginning on December 25, 2016. The leaves were sprayed 3 times every 7 days. There were four pots in each group, of which 3 pots were used per replication. Flower samples were collected during the main flowering period (May-June). The flowering process of the plants was observed and recorded, and the flowering period was divided into 4 stages, as shown in Fig. 1.

\section{PA Analysis}

The PA extraction method was a modified version of the method of Hu et al. (2012) A total of $0.5 \mathrm{~g}$ of fresh petals was weighed and homogenized by the addition of $3.2 \mathrm{~mL}$ of $5 \%(\mathrm{v} / \mathrm{v}) \mathrm{HClO}_{4}$ in an ice bath followed by incubation at $4^{\circ} \mathrm{C}$ for $1 \mathrm{~h}$. The homogenate was subsequently centrifuged at $12,000 \times \mathrm{g}$ for 30 min $\left(4^{\circ} \mathrm{C}\right)$, and the pellet was used for measuring the insoluble bound PAs. Then, the supernatant was assayed for free and soluble conjugated PAs, as described in the supplementary materials (Methods S1).

\section{Extraction and Quantification of Endogenous GAs}

Endogenous GAs were measured according to the method of Pan et al. (2010) A total of $0.5 \mathrm{~g}$ of fresh petals was ground to a fine powder, and $5 \mathrm{~mL}$ of extractant (2:1:0.002 v/v/v 2-

propanol/water/concentrated $\mathrm{HCl}$ ) was then added, after which the mixture was shaken for $30 \mathrm{~min}\left(4^{\circ} \mathrm{C}\right)$. A total of $1 \mathrm{~mL}$ of dichloromethane was added to each sample, which was then shaken for $30 \mathrm{~min}$ at $4{ }^{\circ} \mathrm{C}$. The samples were subsequently centrifuged at $13,000 \times \mathrm{g}$ for 4 min at $4{ }^{\circ} \mathrm{C}$, and the lower phase was collected. Two drops of concentrated ammonia were added at $35^{\circ} \mathrm{C}$ until near dryness occurred, after which the sample was redissolved in $0.1 \mathrm{~mL}$ of methanol. The sample solution was analyzed by highperformance liquid chromatography-electrospray ionization-tandem mass spectrometry (HPLC-ESI$\mathrm{MS} / \mathrm{MS})$.

\section{Activity of PA Biosynthesis Enzymes}

A total of $1.0 \mathrm{~g}$ of fresh sample tissue and $3.2 \mathrm{~mL}$ of potassium phosphate buffer $(\mathrm{pH} 8.0)$, which contained $0.1 \mathrm{mM}$ phenylmethylsulfonyl fluoride (PMSF), $5 \mathrm{mM}$ dithiothreitol (DTT), $1 \mathrm{mM}$ pyridoxal phosphate (PLP), $5 \mathrm{mM}$ EDTA, $25 \mathrm{mM}$ ascorbic acid (VC) and $0.1 \%$ polyvinylpyrrolidone (PVP), were mixed together. The samples were ground in an ice bath and then centrifuged at $12000 \times \mathrm{g}$ for $40 \mathrm{~min}$ at $4{ }^{\circ} \mathrm{C}$, after which the supernatant and ammonium sulfate were mixed together to a saturation of $40 \%$ and subsequently centrifuged at $12000 \times \mathrm{g}$ for $15 \mathrm{~min}$ at $4{ }^{\circ} \mathrm{C}$. The supernatant and ammonium sulfate were mixed together to a saturation of $60 \%$, incubated at room temperature for $30 \mathrm{~min}$ and then centrifuged at $12000 \times \mathrm{g}$ for $20 \mathrm{~min}$ at $4{ }^{\circ} \mathrm{C}$. The precipitate was then suspended in $3 \mathrm{~mL}$ of $100 \mathrm{mM}$ potassium phosphate buffer ( $\mathrm{pH}$ 8.0; containing $1 \mathrm{mM}$ DTT, $0.1 \mathrm{mM}$ EDTA, and $0.05 \mathrm{mM} \mathrm{PLP}$ ) and dialyzed at $4{ }^{\circ} \mathrm{C}$ for $24 \mathrm{~h}$. The enzyme activity was measured according to the method of Zhao et al. (2003) and measured as described in the supplementary materials (Methods S1).

\section{DAO and PAO Activity Assays}

The activities of PAO and DAO were determined according to the protocol of Su et al. (2005). A total of $0.5 \mathrm{~g}$ of fresh petals was ground in the presence of $1 \mathrm{~mL}$ of $0.1 \mathrm{M}$ potassium phosphate buffer $(\mathrm{pH}$ of 
6.5) and then centrifuged at $10000 \times \mathrm{g}$ for $20 \mathrm{~min}$ at $4^{\circ} \mathrm{C}$, after which the supernatant was sampled for enzyme activity, which was measured as described in the supplementary materials (Methods S1).

\section{Statistical Analysis}

The entire experiment was repeated three times, and the results presented are the averages of three replicates. Differences between treatments were determined by one-way analysis of variance (ANOVA) and Duncan's test for multiple comparisons. A structural equation model (SEM) was used to explain the influence of related components and types on PA metabolism. Structural equation modeling is a multivariate statistical method that is used for model identification, estimation, and verification of various causal models and clearly gives the influence of each relationship. However, this method requires a previous model that is based on basic theory or practical experience (Doncaster 2007). Linear regression was used to evaluate the relationships between $\mathrm{GA}_{3}$, PAs and Rhododendron flowering.

To ensure that the model operation results are reasonable and reliable, it is usually required that the sample multivariate normality test index value be less than 1.96. AMOS is a statistical software package for structural equation modeling that could not only validate various measurement models and different path analysis models but also optimize multigroup analysis and single-group/multigroup competition models. Moreover, AMOS provides a graphical representation of model diagrams and can quickly draw various hypothetical model diagrams. Moreover, the output report data are easy to interpret. Therefore, the model analysis process was carried out via AMOS 21.0 software.

\section{Results}

\section{Flowering Time of Rhododendron}

Table 1 illustrates the changes in flowering time after treatment with $\mathrm{GA}_{3} / \mathrm{Spd}$ applications. Exogenous $\mathrm{GA}_{3}$ applications advanced the initial flowering of Rhododendron but delayed flowering in the Spd treatments (Table 1). In detail, the initial flowering with $1600 \mathrm{mg} \cdot \mathrm{L}^{-1} \mathrm{GA}_{3}$ application occurred 6 days earlier than that in the control. Conversely, the initial flowering time was delayed in Spd-treated plants. For example, with Spd applications, the initial flowering time was delayed $7 \sim 12$ days. Interestingly, when 1 $600 \mathrm{mg} \cdot \mathrm{L}^{-1} \mathrm{GA}_{3}$ was combined with $0.1 \mathrm{mM} \mathrm{Spd}$, the initial flowering occurred just 2 days earlier than it did in the control solution. Moreover, all applications prolonged the flowering lifespan, and the flowering time rose to a greater extent with Spd applications. However, when $\mathrm{GA}_{3}$ was combined with $\mathrm{Spd}$, the flowering time was only prolonged 1 day compared with that of the control. 
Table 1

Effects of $\mathrm{GA}_{3}$ and Spd on the flowering time of Rhododendron

\begin{tabular}{|llllll|}
\hline Treatment & $\begin{array}{l}\text { Squaring } \\
\text { stage } \\
\text { (Day/month) }\end{array}$ & $\begin{array}{l}\text { Early flowering stage } \\
\text { (Day/month) }\end{array}$ & $\begin{array}{l}\text { Blooming } \\
\text { stage } \\
\text { (Day/month) }\end{array}$ & $\begin{array}{l}\text { End of } \\
\text { flowering } \\
\text { (Day/month) }\end{array}$ & $\begin{array}{l}\text { Days of } \\
\text { blossoming } \\
\text { (Day) }\end{array}$ \\
\hline CK & $7 / 5$ & $10 / 5$ & $12 / 5$ & $15 / 5$ & 8 \\
\hline T1 & $3 / 5$ & $7 / 5$ & $10 / 5$ & $14 / 5$ & 11 \\
\hline T2 & $1 / 5$ & $6 / 5$ & $13 / 5$ & $16 / 5$ & 15 \\
\hline T3 & $2 / 5$ & $6 / 5$ & $10 / 5$ & $14 / 5$ & 12 \\
\hline T4 & $10 / 5$ & $14 / 5$ & $19 / 5$ & $23 / 5$ & 13 \\
\hline T5 & $15 / 5$ & $21 / 5$ & $29 / 5$ & $3 / 6$ & 19 \\
\hline T6 & $12 / 5$ & $17 / 5$ & $21 / 5$ & $27 / 5$ & 15 \\
\hline T7 & $5 / 5$ & $9 / 5$ & $11 / 5$ & $14 / 5$ & 9 \\
\hline
\end{tabular}

\section{$\mathrm{GA}_{3}$ Levels}

In the current work, $\mathrm{GA}_{3}$ levels changed appreciably during flower senescence (Fig. 2D). The level of $\mathrm{GA}_{3}$ demonstrated an upward trend and peaked at stage 3 but then decreased. Applications of flowers with different $\mathrm{GA}_{3}$ and Spd concentrations resulted in an increase in $\mathrm{GA}_{3}$. This gradual increase was followed by a drastic rise at stage 3 and then declined rapidly. Moreover, the highest $\mathrm{GA}_{3}$ level was recorded in response to the $\mathrm{GA}_{3}$ plus Spd application at all times, and the treatment with $\mathrm{GA}_{3}$ resulted in a greater accumulation of endogenous $\mathrm{GA}_{3}$ with respect to the Spd applications.

\section{PA Levels}

The PA levels in different forms and their ratios with $\mathrm{GA}_{3}$ and Spd applications were determined. In general, flower senescence was accompanied by a decrease in the free $(F)$ form from stage 1 to stage 2 and increased thereafter. A steady increase in conjugated (C) and bound (B) form PAs was recorded during flower senescence (Fig. 2A-C). In addition, three PAs increased with all applications to different extents. In detail, at stage 1, compared with the control, F Put content rose $1.02 \sim 1.45-, 0.82 \sim 1.31$ - and 1.37-fold with $\mathrm{GA}_{3}$, Spd and $\mathrm{GA}_{3}+$ Spd applications, respectively. The $\mathrm{F}$ fraction of Put rose $0.89 \sim 1.03-$ fold with $\mathrm{GA}_{3}$ but decreased $0.81 \sim 0.89$ - and 0.85 -fold with $\mathrm{Spd}$ and $\mathrm{GA}_{3}+\mathrm{Spd}$ applications, respectively. Moreover, all applications increased $F$ Spd and Spm content, increased the F fraction of Spm, but decreased the $F$ fraction of Spd. C PA contents increased with $\mathrm{GA}_{3}$ and Spd to different extents. In general, the increase in C PA content was as follows: $\mathrm{GA}_{3}+\mathrm{Spd} \square \mathrm{Spd} \square \mathrm{GA}_{3}$. All applications increased the $\mathrm{C}$ fraction of Put and decreased the $C$ fraction of Spm, while the $C$ fraction of Spd decreased $0.95 \sim 0.98$ fold with $\mathrm{GA}_{3}$ but rose 0.97 1.04- and 1.02-fold with Spd and $\mathrm{GA}_{3}+$ Spd applications, respectively. In the 
case of the B form, $\mathrm{GA}_{3}$ and Spd increased the B PA contents and B fractions of Put and Spd, but decreased the $B$ fraction of Spm; During stages 3 and 4, three forms of PA contents increased with $\mathrm{GA}_{3}$ and Spd applications. Both $\mathrm{GA}_{3}$ and Spd decreased the $F$ fractions of Put and Spd but increased the $F$ fraction of Spm. The $C$ fractions of Put, Spd and Spm increased with all applications at stage 3, except for $0.1 \sim 1 \mathrm{mM}$ Spd and $\mathrm{GA}_{3}+$ Spd applications. Intriguingly, $\mathrm{GA}_{3}$ decreased the $\mathrm{C}$ fraction of Put, which increased with Spd and $\mathrm{GA}_{3}+\mathrm{Spd}$ applications at stage 4. The opposite behavior observed for the $\mathrm{C}$ fraction of Spm. Regarding the B form, all applications increased the F fraction of Put, but decreased the F fractions of Spd and Spm.

In the current work, various $\mathrm{GA}_{3}$ and Spd concentrations affected PA ratios. In detail, at stage 1, the $\mathrm{Spd} /$ Put ratio in the flowers decreased $0.97 \sim 1.07$-fold compared with the control with $\mathrm{GA}_{3}$ application and rose $1.00 \sim 1.16$ - and 1.06-fold with Spd and $\mathrm{GA}_{3}+\mathrm{Spd}$ applications, respectively. The Spd/Spm ratios in the flowers were $0.78 \sim 0.97-, 0.56 \sim 0.71$ - and 0.56-fold compared with the control with $\mathrm{GA}_{3}$, Spd and $\mathrm{GA}_{3}+\mathrm{Spd}$ applications, respectively. During stages 3 and $4, \mathrm{GA}_{3}$ significantly improved the Spd/Put ratio at stage 3 , while Spd and $\mathrm{GA}_{3}+\mathrm{Spd}$ applications significantly decreased the Spd/Put ratio, and similar behavior was observed for the Spd/Spm ratio at stages 3 and 4. The dynamic PA levels in different forms and ratios indicated that $\mathrm{GA}_{3}$ and Spd play significant roles in modulating Rhododendron flowering time and senescence.

\section{Activities of PA Biosynthetic/Degradative Enzymes}

The trend of ODC and SAMDC was quite comparable and showed a rise from stage 1 to stage 3 and then a decline (Fig. 3B-C), the rise was faster in SAMDC than in ODC. However, this behavior was opposite to that found for ADC activity (Fig. 3A). The ADC, SAMDC and ODC activities increased significantly in response to $\mathrm{GA}_{3}$ and Spd applications. The highest $A D C$ activity was recorded in response to $0.01 \mathrm{mM}$ Spd application during stage 3 to stage 4 and $1600 \mathrm{mg} \cdot \mathrm{L}^{-1} \mathrm{GA}_{3}+0.1 \mathrm{mM} \mathrm{Spd}$ application during stage 1 to stage 2, whereas the highest ODC and SAMDC activity was recorded in response to $1600 \mathrm{mg} \cdot \mathrm{L}^{-1} \mathrm{GA}_{3}$ + $0.1 \mathrm{mM}$ Spd application.

Flower senescence was accompanied by a rise of PAO from stage 1 to stage 3 and then a decrease, whereas DAO showed a continuous increase (Fig. 4A-B). GA 3 and Spd improved the activity of DAO and PAO. Notably, the activity declined from stage 1 to stage 2 with $\mathrm{GA}_{3} / \mathrm{Spd}$ applications. The highest DAO and PAO activity were recorded in response to $1600 \mathrm{mg} \cdot \mathrm{L}^{-1} \mathrm{GA}_{3}+0.1 \mathrm{mM}$ Spd application.

\section{Relationships of $\mathrm{GA}_{3}$ and PAs to Rhododendron flowering}

Regression analysis illustrated that the flowering time was significantly and positively correlated with the mean contents of soluble conjugated Put, Spd, and Spm, insoluble bound Put, Spd, and Spm, fractions of soluble conjugated Put and Spm, and soluble conjugated Put, Spd and Spm ( $r=0.432 \sim 0.690, p=0.01$; Table 2). The correlations of flowering time with the ratios of Spd/Put $(r=-0.207, p=0.05), S p d / S p m$, 
fractions of free Put, Spd and Spm were significant and negative ( $r=-0.477$ to $-0.639, p=0.01)$, whereas the correlations were insignificant among flowering time with contents of $\mathrm{GA}_{3}$, free Put, Spd, Spm, and the fraction of soluble conjugated Spd ( $r=-0.006$ to $0.145, p>0.05)$. 
Table 2

Correlations of the flowering time with the mean contents of free polyamines, soluble conjugated polyamines, insoluble bound polyamines, $\mathrm{GA}_{3}$ content, ratios of $\mathrm{Spd} / \mathrm{Spm}$, Spd/Put, fractions of free polyamines, soluble conjugated polyamines and insoluble bound polyamines during the flowering process of petals of Rhododendron

\section{Correlation with}

Flowering time

free polyamine contents

Putrescine (Put)

$-0.073$

Spermidine (Spd)

0.071

Spermine (Spm)

0.145

Content of soluble conjugated polyamines

$\begin{array}{ll}\text { Put } & 0.598^{\star \star} \\ \text { Spd } & 0.432^{\star \star} \\ \text { Spm } & 0.624^{\star \star}\end{array}$

Content of insoluble bound polyamines

Put

0.690 **

Spd

$0.627^{\star *}$

Spm

$0.675^{\star *}$

$\mathrm{GA}_{3}$ content

$-0.071$

Spd/Spm

$-0.503^{\star *}$

Spd/Put

$-0.207 *$

Fraction of free polyamines

Put

$-0.639 * *$

Spd

$-0.540 \star \star$

Spm

$-0.477 \star \star$

Fraction of soluble conjugated polyamines

Put

$0.449 * \star$

Spd

$-0.006$

Spm

$0.392^{\star \star}$

${ }^{*}, \star \star$ Correlation significance at $p=0.05$ and $p=0.01$ levels, respectively $(\mathrm{n}=3)$. Data used for calculations are from Figs. 1, 2, 3, 4. 
Fraction of soluble conjugated polyamines

Put $0.664 * \star$

$\star$, $\star *$ Correlation significance at $p=0.05$ and $p=0.01$ levels, respectively $(\mathrm{n}=3)$. Data used for calculations are from Figs. 1, 2, 3, 4.

\section{Discussion}

\section{$\mathrm{GA}_{3}$ and Spd Are Associated with Rhododendron Flowering Time}

Flowering is a complex process that is regulated by a network of in vitro and in vivo factors. GA is one of the most widely studied hormones for regulating flowering time (Silva et al. 2019; Sven Eriksson and Nilsson 2006). Evidence suggests that GA promotes flowering by suppressing the expression of the DELLA group of proteins and promoting the expression of floral homeotic genes (Mutasa-Gottgens and Hedden 2009). In this work, exogenous $\mathrm{GA}_{3}$ advanced the initial flowering time, and this finding is consistent with previous observations for Rhododendron (Chang and Sung 2000), which demonstrated that $\mathrm{GA}_{3}$ promotes bud development and advances flowering. Moreover, $\mathrm{PA}$ is another important regulator of floral initiation and development (Matsoukas et al. 2012; Srikanth and Schmid 2011). Among previous studies, some observed flowering advanced in Arabidopsis thaliana (Molesini et al. 2015), Dendranthema morifolium (Dong-Hua et al. 2014) with PA application, while the opposite result was found by Applewhite et al. (2010) and Ahmed et al. (2017). These differences may contribute to plant species, treatment parts and treatment dose. In the present work, the flowering time was delayed for a long time after Spd application (Table 1), which is consistent with previous observations for $S$. alba (Havelange et al. 1996). Notably, advanced or delayed flowering is not accompanied by an increase in the treatment dose, suggesting that flowering requires an appropriate treatment dose in Rhododendron; the higher the level, the more the flowering cannot be generalized (Pal et al. 2015). Intriguingly, when $\mathrm{GA}_{3}$ was combined with Spd, the flowering time advanced just 1 day compared with the control. This finding is similar to previous observations of Alcázar et al. (2005), who demonstrated that the leaves treated with gibberellin reversed the inhibition of flowering. We speculate that there is an interactive effect of $\mathrm{GA}_{3}$ and Spd on the flowering time of Rhododendron, but this hypothesis requires further study.

\section{$\mathrm{GA}_{3}$ and Spd Delayed Rhododendron Floral Senescence}

Floral senescence is the final portion of flower development. Usually, floral senescence is accompanied by dynamic changes in the levels of endogenous hormones, which modulate intricate networks of signaling events that control the senescence program (van Doorn and Woltering 2008; Zhang and Zhou 2013). GA is a crucial hormone that suppresses floral senescence. In the current work, flower longevity significantly improved by $\mathrm{GA}_{3}$ application (Table 1); this finding is consistent with previous observations for rose (Saks and Staden 1993), Sandersonia aurantiaca (Eason and R. 2002), daffodil (Sheikh and 
Farooq 1999) and lily (Domenico 2018). Delayed senescence may be attributed to integrated membrane maintenance and reduced electrolyte leakage (Sabehat and Zieslin 1994). However, new evidence has been obtained by Lu et al. (2014) showing that the antagonistic effect of GAs on ethylene during rose petal senescence is mediated by the RhHB1 gene.

PAs are considered to be important growth regulators, especially associated with plant senescence. A decrease in PA content is proven to be a senescence signal (Duan 2006). PAs delay senescence by retarding membrane deterioration, RNase and protease activity (Kaur-Sawhney et al. 2003). Here, the flowering lifespan extended with Spd application, which was comparable to reports in rose (Tatte and Ahlawat 2015), carnation (Lee et al. 1997), anthurium (Simões et al. 2018) and Nicotiana plumbaginifolia L. (Domingos et al. 2016). Both $\mathrm{GA}_{3}$ and PAs were demonstrated to be delayed in plant senescence; hence, the combinations of $\mathrm{GA}_{3}+\mathrm{PAs}$ can postpone senescence synergistically.

\section{$\mathrm{GA}_{3}$ and Spd Influence Flowering and Senescence by Modulating PA Metabolism}

Initially, the PA levels do not always peak during senescence, depending on the type of senescence model and whether PAs are induced by external or natural factors (Del Duca et al. 2014). In the present work, senescence of these petals was accompanied by a rapid decline in F PAs in the petals during the early stages and a continuous increase in C and B PAs, which was comparable to the report of Qin et al. (2019) in apple but different from that of Huang et al. (2004) in P. tuberosa. The reason for such a decline may be a decline in the $F$ fraction and a transformation from the $F$ form to the $C$ form at early stages (Fig. 2AC). In addition, concomitant increases in C and B PAs may be attributed to PA degradation (Fig. 5) and an increase in $B$ and $C$ fraction PAs (Fig. 2A-C), as well as a decrease in F PA levels and an increase in the conjugated pool associated with the initiation of cell expansion (Altamura et al. 1993). On the other hand, the increase in C PA is associated with cell wall organization, extension or rigidity. The B PAs, which result from C PAs (Fig. 5) moving to cell wall hemicelluloses and/or lignin or to cell wall proteins via PAconjugating enzyme transglutaminase (TGase), may form protein polymers or heteropolymers with polysaccharides, indicating the significance of B PA in the cell walls (Cai et al. 2015b). However, the specific mechanism remains unclear and requires further research.

The homeostatic regulation of cellular PA levels is a dynamic balance of biosynthesis, catabolism, interconversion and conjugation and is important for plant development, such as flowering (Majumdar et al. 2016; Yu et al. 2019), whereas the regulatory effect of $\mathrm{GA}_{3}$ and $\mathrm{Spd}$ remains largely unknown. Thus, we analyzed the key enzymes involved in PA metabolism and the interconversion of PA forms/components with $\mathrm{GA}_{3}$ and Spd applications. As shown in Fig. 2, after spraying with $\mathrm{GA}_{3}$ and $\mathrm{Spd}$, the PA and GA levels increased. The reason for such a result may mainly be attributed to the permeation of exogenous Spd in addition to the synthesis of new Spd (Qin et al. 2019). Another direct cause of an increase in PA may be attributed to the effect of $\mathrm{GA}_{3}$ (Fig. 5), which contributed to a direct effect on Spd (c.f. 0.27). Notably, the $\mathrm{GA}_{3}$ pathway had to a negative effect on Spm (Fig. 5). Namely, Spm may have 
had a positive effect on $\mathrm{GA}_{3}$ (Fig. 5), which was consistent with previous observations for maize (Li et al. 2018) and sweet corn seed embryos (Huang et al. 2017). During stages 3 and 4, the contents of $C$ and $B$ PAs were significantly improved by $\mathrm{GA}_{3}$ and Spd applications, which may contribute to longer flower lifespan (Table 2). Intriguingly, when $\mathrm{GA}_{3}$ was combined with $\mathrm{Spd}$, the highest $\mathrm{C}$ and $\mathrm{B}$ PA contents were not consistent with the longest flower lifespan, indicating that other factors affect senescence.

Aribaud et al. (1998) demonstrated that the relative polyamine proportion and their metabolism are more important than their endogenous content in the development processes. In this study, PA forms and ratios were also altered by $\mathrm{GA}_{3}$ and Spd applications. $\mathrm{GA}_{3}$ treatment increased the $\mathrm{F}$ fraction of Put and decreased the Spd/Put ratio, Spd and the $\mathrm{GA}_{3}+$ Spd applications increased the $\mathrm{C}$ and $\mathrm{B}$ fractions of Put and the Spd/Put ratio at stage 1 . The results infer that $\mathrm{GA}_{3}$ promotes flowering by decreasing the $S p d / P u t$ ratio, whereas Spd delayed flowering by increasing the Spd/Put ratio and the $C$ and $B$ fractions of PAs. The Spd/Put ratio decreased with $\mathrm{GA}_{3}+\mathrm{Spd}$ application, and the $\mathrm{C}$ and $\mathrm{B}$ fractions of PAs increased, which may contribute to the advancement of the initial flowering time by $2 \mathrm{~d}$ because flowering time is significantly positively correlated with the $\mathrm{C}$ and $\mathrm{B}$ fractions of PAs and significantly negatively correlated with the Spd/Put ratio (Table 2). The reasons for the increase in the $\mathrm{F}$ Put fraction by $\mathrm{GA}_{3}$ may be due to the direct effect on Spd (Fig. 5), which is converted into Put and synthesizes new F Put. The decrease in $F$ Put and increase in $B$ and $C$ Put with Spd application may contribute to Spd accelerating the conversion of $F$ into $C$ and $C$ into $B$ forms (Fig. 5). Moreover, the Put level is similar to that of $\mathrm{GA}_{3}$ and Spd at stage 1 (Fig. 2A), and the Spd level is significantly higher with Spd application compared with $\mathrm{GA}_{3}$ application (Fig. 2B); thus, the decrease in the Spd/Put ratio with $\mathrm{GA}_{3}$ application may be attributable to $\mathrm{GA}_{3}$ accelerating conversion of Spd into Put, and the increase in the Spd/Put ratio with Spd application may contribute to the significant increase in the Spd level. The results infer that the role of the $F$ Put fraction and Spd/Put ratio in flowering time could be in response to $\mathrm{GA}_{3}$ and $\mathrm{Spd}$, as suggested by Handa and Mattoo (2010b) and Nambeesan et al. (2019) that PA ratios are associated with N:C balance and flower developmental progress. Moreover, flower senescence is accompanied by a decrease in the $\mathrm{F}$ fractions of Put and Spd and increases in the F fraction of Spm, the $C$ fractions of Put, Spd, and Spm and the Spd/Spm ratio with GA3 and Spd applications (Fig. 2B-C, Fig. 4D). In general, the increases in the C fraction of Pas and the Spd/Spm ratio and the decreases in the $F$ fractions of Put and Spd were followed by: $\mathrm{Spd} \square \mathrm{GA}_{3} \square G A_{3}+\mathrm{Spd}$. It is significant that Spd delaying flower senescence showed the best effect because the $\mathrm{F}$ fraction of PAs and Spd/Spm were significantly negatively correlated with flowering time, whereas the $C$ and $B$ fractions of PAs were significantly positively correlated with flowering time (Table 2). A direct cause of the increase in the C Spd fraction and the F Spm fraction is that $\mathrm{GA}_{3}$ and $\mathrm{Spd}$ significantly improved the PAO activity (Fig. 4A), which could accelerate the conversion of F PA into C PA and C PA into B PA (Wang et al. 2019). Despite the significant improvements in the contents of Spd and Spm by $\mathrm{GA}_{3}$ and Spd applications during flowering, the Spd/Spm ratio decreased (c.f. 0.91) (Fig. 5). It has been reported that higher Spm levels decrease ROS accumulation and induce nitric oxide (NO) production. Spm may be a signaling metabolite that provides protection delay senescence via metabolic conversions involving ascorbate/dehydro-ascorbate redox state modification, changes in sugar and 
nitrogen metabolism, cross-talk with ethylene biosynthesis and thereby delayed senescence (SequeraMutiozabal et al. 2016). Moreover, the increase in the C Spd fraction and the F Spm fraction may also result in an increase in the flower lifespan. PA interaction with cell wall components may be responsible for changes in cell wall rigidity (Berta et al. 2010). The conjugates are significant not only for their modulation of PA forms inside the cell but also for their interaction with cell wall components (Bagni and Tassoni 2001). In addition, conjugation of PA might be a regulatory mechanism to control its level within a non-toxic range for plant survival (Alcázar et al. 2005). Furthermore, ethylene triggers senescence in plants, and its synthesis pathway directly competes with the synthesis of PAs by the use of S-adenosyl methionine (SAM) in both pathways (Mehta et al. 2002; Pandey et al. 2000; Sobieszczuk-Nowicka 2017). In the present study, flower senescence was accompanied by an increase in the contents of $F$ Spd and Spm (Fig. 2B-C). GA ${ }_{3}$ and Spd significantly improved the PA levels during flowering, especially for free Spd and Spm levels and the F Spm fraction. This increase may have contributed to the improvement of SAMDC activity (Fig. 3C, Fig. 5) and expression levels of SAMDC. Antisenescence agents in some tissues have been attributed to F PAs, which may be responsible for the reduction in ethylene production (Saftner and Baldi 1990). This result indicates that higher $F$ fractions of Spd and Spm may inhibit ethylene production, as demonstrated by Chen et al. (2013) in rice. Based on these results, one can infer that exogenous $\mathrm{Spd}$ and $\mathrm{GA}_{3}$ regulated PA metabolism by increasing the content and altering the form, components and ratios of PAs.

One possible explanation for the differences in PA content among the treatments is that the responses to flowering of PA biosynthetic/degradative enzymes are different. In the PA biosynthetic pathway, ornithine or arginine is decarboxylated by ODC or ADC to form Put. In general, the highest levels of endogenous PAs and PA synthetase activity were discovered in the meristem and growing cells, and the lowest were in senescent tissues (Chen et al. 2019). Here, flower development was accompanied by an increase in the activities of ODC and SAMDC and a decrease at stage 4 (Fig. 3B-C). Exogenous Spd significantly improves ADC, ODC and SAMDC activities, possibly due to the increased MdADC1 and MdODC1 expression and even MdSAMDC2 transcription (Qin et al. 2019). High activities of ODC and SAMDC contributed to the positive effects on Spd and Spm contents (Fig. 5). However, the level of ADC presented an opposite trend, and a continuous increase in $C$ and B PAs was found, indicating that ADC had a negative effect on PA levels (Fig. 5).

In addition to the PA biosynthetic pathway, increasing evidence suggests that the PA degradative pathway also plays a signaling role in developmental processes (Wang et al. 2019). NO is one of the signals that control flowering (He et al. 2004)(He et al., 2004). DAO and PAO resulted in a high level of PAs and play a role in flowering since PA and NO share some common signal transduction pathways (Wimalasekera et al. 2011). Oxidation of PAs by PAOs contributes to the regulation of PA homeostasis (Angelini et al. 2010). Moreover, PA catabolism induces hydrogen peroxide $\left(\mathrm{H}_{2} \mathrm{O}_{2}\right)$ and cytotoxic products, which is considered to be a possible mechanism of PA association with programmed cell death (PCD) (Cai et al. 2015a; Cai et al. 2015b; Del Duca et al. 2014; Yoda et al. 2006). In the present study, senescence of these flowers was accompanied by a minimal decline in the activity of DAO at the initial flowering 
stage and then an increase; PAO presented an opposite trend (Fig. 4A-B). F PA decreased at the initial flowering stage, and $C$ and $B$ PA increased throughout flowering. One possible explanation is that the increase in PAO (Fig. 4A) could accelerate the conversion of F PA into C PA and C PA into B PA (Wang et al. 2019). However, the high level of F Spm could function as negative feedback, thus inhibiting the production of Spd (Fig. 5) (Hu et al. 2012). The high level of Spd mainly contributed to Put (c.f. 0.63), SAMDC (c.f. 0.52) and $\mathrm{GA}_{3}$ (c.f. 0.27) (Fig. 5). Thus, the longer flower longevity of application with Spd may be associated with its capacity to maintain high activities of DAO and PAO. Notwithstanding, the longest flowering time was not associated with the highest concentration of Spd (1 mM). When $\mathrm{GA}_{3}$ combined with Spd, the highest level of endogenous PA (Fig. 2A-C) was accompanied by a significant increase in DAO and PAO (Fig. 4A-B), but the flowering time was only prolonged 1 day (Table 1). Appropriate hormonal action demands polyamine homeostasis (Carbonell and Blazquez 2009). One possible explanation is that the increase in endogenous PA concentration was accompanied by an increase in DAO (Fig. 4B). When PAs are catabolized, an oxidized product of $\mathrm{H}_{2} \mathrm{O}_{2}$ is a signaling compound that activates the signaling pathway and contributes to delaying senescence (Moschou et al. 2008). However, when PA-derived $\mathrm{H}_{2} \mathrm{O}_{2}$ is not quenched properly, the process may lead to PCD rather than delay senescence (Moschou et al. 2008). Moreover, the flowering time was longer with Spd application than with $\mathrm{GA}_{3}$ application (Table 1). Based on these results, one can infer that Spd directly participated in PA metabolism and that $\mathrm{GA}_{3}$ delayed flower senescence by modulating PA metabolism via Spd (Fig. 5). Our results collectively demonstrate that endogenous PA contents, forms, and ratios and PA biosynthetic/degradative enzymes, as well as developmental stages of flowering, were altered markedly and regularly after exogenous $\mathrm{Spd}$ and $\mathrm{GA}_{3}$ applications, thereby delaying flower senescence.

\section{Conclusion}

In conclusion, moderate $\mathrm{GA}_{3}$ and $\mathrm{Spd}$ concentrations altered the initial flowering time and delayed flower senescence in Rhododendron. $\mathrm{GA}_{3}$ accelerated flower development was closely associated with an enhanced F Put fraction and a decrease in the Spd/Put ratio at stage 1, whereas Spd slowed flower developmental progress and contributed to an increase in the $C$ and $B$ Put fractions and Spd/Put ratio. There was a potential antagonistic effect of $\mathrm{GA}_{3}$ and $\mathrm{Spd}$ on flowering time. Moreover, $\mathrm{GA}_{3}$ and $\mathrm{Spd}$ prolonged flowering time by decreasing the $\mathrm{Spd} / \mathrm{Spm}$ ratio. Another reason could be the increases in the $C$ and $B$ fractions of PAs. In addition, all applications promoted the PA levels and key enzymes involved in PA metabolism. A potential metabolic interaction or competition between higher free PAs (Spd and Spm) and ethylene biosynthesis mediated the effects of $\mathrm{GA}_{3}$ and $\mathrm{Spd}$ on flower senescence, but further study of the mechanism is needed. For many physiological processes, it is not the presence of "high" PAs that matters, but the concentration of "adequate" PAs. Furthermore, the PA fraction and ratio are indeed significant for flowering in Rhododendron.

\section{Declarations}

\section{Acknowledgments}


This study was partially supported by the Development on Key Technologies of Introduction, Utilization and Industrialization of Rhododendron Germplasm Resources (funding No.: 2015KFN06) and the R \& D of Key Technologies for Excavation and Utilization of Commercial Resources and Cultivation of Rhododendrons (funding No.: 2015-NY02-00023-NC). We appreciate the editors and two anonymous reviewers for their constructive comments, as well as the assistant researchers who worked partially on this study but were not recorded in the authorship.

\section{Compliance with Ethical Standards}

No potential conflict of interest was reported by the authors.

\section{References}

Ahmed, S., Ariyaratne, M., Patel, J., Howard, A. E., Kalinoski, A., Phuntumart, V., et al. (2017). Altered expression of polyamine transporters reveals a role for spermidine in the timing of flowering and other developmental response pathways. Plant Sci. 258, 146-155. doi:10.1016/j.plantsci.2016.12.002

Ahou, A., Martignago, D., Alabdallah, O., Tavazza, R., Stano, P., Macone, A., et al. (2014). A plant spermine oxidase/dehydrogenase regulated by the proteasome and polyamines. J. Exp. Bot. 65, 1585-1603. doi:10.1093/jxb/eru016

Alagna, F., Cirilli, M., Galla, G., Carbone, F., Daddiego, L., Facella, P., et al. (2016). Transcript Analysis and Regulative Events during Flower Development in Olive (Olea europaea L.). Plos One. 11. doi:10.1371/journal.pone.0152943

Alcázar, R., Garcíamartínez, J. L., Cuevas, J. C., Tiburcio, A. F. and Altabella, T. (2005). Overexpression of ADC2 in Arabidopsis induces dwarfism and late-flowering through GA deficiency. Plant J. 43, 425-436. doi:10.1111/j.1365-313X.2005.02465.x

Altamura, M. M., Torrigiani, P., Falasca, G., Rossini, P. and Bagni, N. (1993). Morpho-funcional Gradients in Superficial and Deep Tissues along Tobacco Stem: Polyamine Levels, Biosynthesis and Oxidation, and Organogenesis in vitro. J. Plant Physiol. 142, 543-551. doi:10.1016/S0176-1617(11)80396-2

And, P. T. E. and Malmberg, R. L. (1989). Do Polyamines Have Roles in Plant Development? Annu.rev.plant Physiol.plant Mol.biol. 40, 235-269. doi:10.1146/annurev.pp.40.060189.001315

Angelini, R., Cona A., Federico R., Fincato P., Tavladoraki P. and Tisi A. (2010). "Plant amine oxidases "on the move": an update." Plant physiology \& biochemistry. PPB. 48, 560-564. doi:

10.1016/j.plaphy.2010.02.001

Applewhite, P. B., Kaursawhney, R. and Galston, A. W. (2000). A role for spermidine in the bolting and flowering of Arabidopsis. Physiol. Plant. 108, 314-320. doi:10.1034/j.1399-3054.2000.108003314.x 
Aribaud, M., Kevers, C., Martin-Tanguy, J. Gaspar, T. (1998). Low activity of amine-oxidases and accumulation of conjugated polyamines in disfavour of organogenic programs in Chrysanthemum leaf disc explants. Plant Cell, Tissue \& Organ Culture. 55, 85-94. doi: 10.1023/A:1006153806610

Bagni, N. and Tassoni, A. (2001). Biosynthesis, oxidation and conjugation of aliphatic polyamines in higher plants. Amino Acids. 20, 301-317. doi:10.1007/s007260170046

Bagni, N. and Tassoni, A. (2006). The role of polyamines in relation to flower senescence. Floriculture Ornamental \& Plant Biotechnology. 1536, 855-856

Baron, K. and Stasolla, C. (2008). The role of polyamines during in vivo and in vitro development. In Vitro Cell. Dev. Biol. Plant. 44, 384-395. doi:10.1007/s11627-008-9176-4

Berta, G., Altamura, M. M., Fusconi, A., Cerruti, F., Capitani, F. and Bagni, N. (2008). The plant cell wall is altered by inhibition of polyamine biosynthesis. New Phytol. 137, 569-577. doi:10.1046/j.14698137.1997.00868.x

Cai, G., Della, M. M., Faleri, C., Fattorini, L., Aloisi, I., Serafini-Fracassini, D., et al. (2015). Spermine either delays or promotes cell death in Nicotiana tabacum L. corolla depending on the floral developmental stage and affects the distribution of transglutaminase. Plant Science An International Journal of Experimental Plant Biology. 241, 11-22. doi:10.1016/j.plantsci.2015.09.023

Cai, G., Sobieszczuk-Nowicka, E., Aloisi, I., Fattorini, L., Serafini-Fracassini, D. and Del Duca, S. (2015). Polyamines are common players in different facets of plant programmed cell death. Amino Acids. 47, 2744. doi:10.1007/s00726-014-1865-1

Carbonell, J. and Blázquez, M. A. (2009). Regulatory Mechanisms of Polyamine Biosynthesis in Plants. Genes \& Genomics. 31, 107-118. doi:10.1007/BF03191144

Chang, Y. S. and Sung, F. H. (2000). Effects of gibberellic acid and dormancy-breaking chemicals on flower development of Rhododendron pulchrum Sweet and R. scabrum Don. Scientia Horticulturae. 83, 331-337. doi:10.1016/S0304-4238(99)00111-9

Chen, D. D., Shao, Q. S., Yin, L. H., Younis, A. and Zheng, B. S. (2019). Polyamine Function in Plants: Metabolism, Regulation on Development, and Roles in Abiotic Stress Responses. Frontiers in plant science. 9. doi:10.3389/fpls.2018.01945

Chen, L., Chen, Q., Zhu, Y., Hou, L. and Mao, P. (2016). Proteomic Identification of Differentially Expressed Proteins during Alfalfa (Medicago sativa L.) Flower Development. Frontiers in plant science. 7. doi:10.3389/fpls.2016.01502

Chen, T., Xu, Y., Wang, J., Wang, Z., Yang, J. and Zhang, J. (2013). Polyamines and ethylene interact in rice grains in response to soil drying during grain filling. J. Exp. Bot. 64, 2523-2538. doi:10.1093/jxb/ert115 
Choudhary, S., Thakur, S., Jaitak, V. and Bhardwaj, P. (2019). Gene and metabolite profiling reveals flowering and survival strategies in Himalayan Rhododendron arboreum. Gene. 690, 1-10. doi:10.1016/j.gene.2018.12.035

Del Duca, S., Serafini-Fracassini, D. and Cai, G. (2014). Senescence and programmed cell death in plants: polyamine action mediated by transglutaminase. Frontiers in plant science. 5, 120.

doi:10.3389/fpls.2014.00120

Domingos, S., Fino, J., Paulo, O. S., Oliveira, C. M. and Goulao, L. F. (2016). Molecular candidates for earlystage flower-to-fruit transition in stenospermocarpic table grape (Vitis vinifera L.) inflorescences ascribed by differential transcriptome and metabolome profiles. Plant Sci. 244, 40-56.

doi:10.1016/j.plantsci.2015.12.009

Doncaster, C. P. (2007). Structural Equation Modeling and Natural Systems. Fish \& Fisheries. 8, 368-369. doi:10.1111/j.1467-2979.2007.00260.x

Dong-Hua, X. U., Guo, J. E., Lu, X. U., Sun, X. and Sun, X. Z. (2014). The Relationship Between Polyamine Oxidase Activity and Lignin Deposition and Chrysanthemum Flower Bud Differentiation. Acta Agriculturae Boreali-Sinica

Duan, H. G. (2006). The Role of Polyamines in the Ontogeny of Higher Plants. Acta Agriculturae BorealiOccidentalis Sinica

Eason, J. R. (2002). Sandersonia aurantiaca: An evaluation of postharvest pulsing solutions to maximise cut flower quality. New Zealand Journal of Experimental Agriculture. 30, 273-279.

doi:10.1080/01140671.2002.9514224

Eriksson, S., Bohlenius, H., Moritz, T. and Nilsson, O. (2006). GA4 is the active gibberellin in the regulation of LEAFY transcription and Arabidopsis floral initiation. The Plant cell. 18, 2172-2181. doi:10.1105/tpc.106.042317

Fortes, A. M. and Agudelo-Romero, P. (2018). Polyamine Metabolism in Climacteric and Non-Climacteric Fruit Ripening. 1964, 433-447. doi:10.1007/978-1-4939-7398-9_36

Handa, A. K. and Mattoo, A. K. (2010). Differential and functional interactions emphasize the multiple roles of polyamines in plants. Plant Physiol. Biochem. 48, 540-546. doi:10.1016/j.plaphy.2010.02.009

Havelange, A., Lejeune, P., Bernier, G., Kaur-Sawhney, R. and Galston, A. W. (1996). Putrescine export from leaves in relation to floral transition in Sinapis alba. Physiol. Plant. 96, 59-65. doi:10.1111/j.13993054.1996.tb00183.x

He, Y., Tang, R.-H., Hao, Y., Stevens, R. D., Cook, C. W., Ahn, S. M., et al. (2004). Nitric oxide represses the Arabidopsis floral transition. Science (New York, N.Y.). 305, 1968-1971. doi:10.1126/science.1098837 
Hu, X., Zhang, Y., Shi, Y., Zhang, Z., Zou, Z., Zhang, H., et al. (2012). Effect of exogenous spermidine on polyamine content and metabolism in tomato exposed to salinity-alkalinity mixed stress. Plant Physiol. Biochem. 57, 200-209. doi:10.1016/j.plaphy.2012.05.015

Huang, C. K., Chang, B. S., Wang, K. C., Her, S. J., Chen, T. W., Chen, Y. A., et al. (2004). Changes in polyamine pattern are involved in floral initiation and development in Polianthes tuberosa. J. Plant Physiol. 161, 709-713. doi:10.1078/0176-1617-01256

Huang, Y. T., Lin, C., He, F., Li, Z., Guan, Y. J., Hu, Q. J., et al. (2017). Exogenous spermidine improves seed germination of sweet corn via involvement in phytohormone interactions, $\mathrm{H} 2 \mathrm{O} 2$ and relevant gene expression. BMC Plant Biol. 17. doi:10.1186/s12870-016-0951-9

Hummel, I., Couee, I., El Amrani, A., Martin-Tanguy, J. and Hennion, F. (2002). Involvement of polyamines in root development at low temperature in the subantarctic cruciferous species Pringlea antiscorbutica. $J$. Exp. Bot. 53, 1463-1473. doi:10.1093/jexbot/53.373.1463

Kaur-Sawhney, R., Flores, H. E. and Galston, A. W. (1980). Polyamine-induced DNA Synthesis and Mitosis in Oat Leaf Protoplasts. Plant Physiol. 65, 368-371. doi:10.1104/pp.65.2.368

Kaur-Sawhney, R., Tiburcio, A. F., Altabella, T. and Galston, A. W. (2003). Polyamines in plants: An overview. Journal of Cell and Molecular Biology. 2, 1-12

Lee, M. M., Sun, H. L. and Park, K. Y. (1997). Effects of spermine on ethylene biosynthesis in cut carnation (Dianthus caryophyllus L) flowers during senescence. J. Plant Physiol. 151, 68-73. doi:10.1016/S01761617(97)80038-7

Li, L. J., Gu, W. R., Li, J., Li, C. F., Xie, T. L., Qu, D. Y., et al. (2018). Exogenously applied spermidine alleviates photosynthetic inhibition under drought stress in maize (Zea mays L.) seedlings associated with changes in endogenous polyamines and phytohormones. Plant Physiol. Biochem. 129, 35-55. doi:10.1016/j.plaphy.2018.05.017

Lü, P., Zhang, C., Liu, J., Liu, X., Jiang, G., Jiang, X., et al. (2014). RhHB1 mediates the antagonism of gibberellins to $A B A$ and ethylene during rose (Rosa hybrida) petal senescence. Plant J. 78, 578-590. doi:10.1111/tpj.12494

Lu, X. U., Xing, S. T., Sun, X. Z., Guo, J. E. and Dong-Hua, X. U. (2014). Effects of Polyamines on Hormones Contents and the Relationship with the Flower Bud Differentiation in Chrysanthemum. Plant Physiology Journal. 50, 1195-1202. doi:10.13592/j.cnki.ppj.2014.0212

Majumdar, R., Barchi, B., Turlapati, S. A., Gagne, M., Minocha, R., Long, S., et al. (2016). Glutamate, Ornithine, Arginine, Proline, and Polyamine Metabolic Interactions: The Pathway Is Regulated at the PostTranscriptional Level. Frontiers in plant science. 7. doi:10.3389/fpls.2016.00078 
Malmberg, R. L. and Mcindoo, J. (1983). Abnormal floral development of a tobacco mutant with elevated polyamine levels. $305,623-625$. doi:10.1038/305623a0

Masson, P. H., Takahashi, T. and Angelini, R. (2017). Editorial: Molecular Mechanisms Underlying Polyamine Functions in Plants. Frontiers in plant science. 8. doi:10.3389/fpls.2017.00014

Matsoukas, I. G., Massiah, A. J. and Thomas, B. (2012). Florigenic and Antiflorigenic Signaling in Plants. Plant and Cell Physiology. 53, 1827-1842. doi:10.1093/pcp/pcs130

Mehta, R. A., Cassol, T., Li, N., Ali, N., Handa, A. K. and Mattoo, A. K. (2002). Engineered polyamine accumulation in tomato enhances phytonutrient content, juice quality, and vine life. Nat. Biotechnol. 20, 613-618. doi:10.1038/nbt0602-613

Meijón, M., Cañal, M. J., Fernández, H., Rodríguez, A., Fernández, B., Rodríguez, R., et al. (2010). Hormonal Profile in Vegetative and Floral Buds of Azalea: Levels of Polyamines, Gibberellins, and Cytokinins. J. Plant Growth Regul. 30, 74-82. doi:10.1007/s00344-010-9169-5

Meijon, M., Jesus Canal, M., Valledor, L., Rodriguez, R. and Feito, I. (2011). Epigenetic and physiological effects of gibberellin inhibitors and chemical pruners on the floral transition of azalea. Physiol. Plant. 141, 276-288. doi:10.1111/j.1399-3054.2010.01430.x

Molesini, B., Mennella, G., Martini, F., Francese, G. and Pandolfini, T. (2015). Involvement of the Putative NAcetylornithine Deacetylase from Arabidopsis thaliana in Flowering and Fruit Development. Plant and Cell Physiology. 56, 1084-1096. doi:10.1093/pcp/pcv030

Moschou, P. N., Delis, I. D., Paschalidis, K. A. and Roubelakis-Angelakis, K. A. (2008). Transgenic tobacco plants overexpressing polyamine oxidase are not able to cope with oxidative burst generated by abiotic factors. Physiol. Plant. 133, 140-156. doi:10.1111/j.1399-3054.2008.01049.x

Moschou, P. N., Paschalidis, K. A. and Roubelakis-Angelakis, K. A. (2008). Plant polyamine catabolism: The state of the art. Plant signaling \& behavior. 3, 1061-1066. doi:10.4161/psb.3.12.7172

Moschou, P. N., Wu, J., Cona, A., Tavladoraki, P., Angelini, R. and Roubelakis-Angelakis, K. A. (2012). The polyamines and their catabolic products are significant players in the turnover of nitrogenous molecules in plants. J. Exp. Bot. 63, 5003-5015. doi:10.1093/jxb/ers202

Mutasa-Goettgens, E. and Hedden, P. (2009). Gibberellin as a factor in floral regulatory networks. J. Exp. Bot. 60, 1979-1989. doi:10.1093/jxb/erp040

Nambeesan, S. U., Mattoo, A. K. and Handa, A. K. (2019). Nexus Between Spermidine and Floral Organ Identity and Fruit/Seed Set in Tomato. Frontiers in plant science. 10. doi:10.3389/fpls.2019.01033

Naseri, S., Gholami, M. and Baninasab, B. (2019). Changes in polyamines during bud dormancy in almond cultivars differing in their flowering date. Scientia Horticulturae. 258. 
doi:10.1016/j.scienta.2019.108788

Nölke, G., Schneider, B., Fischer, R. and Schillberg, S. (2005). Immunomodulation of polyamine biosynthesis in tobacco plants has a significant impact on polyamine levels and generates a dwarf phenotype. Plant Biotechnol. J. 3, 237-247. doi:10.1111/j.1467-7652.2005.00121.x

Pál, M., Szalai, G. and Janda, T. (2015). Speculation: Polyamines are important in abiotic stress signaling. Plant Sci. 237, 16-23. doi:10.1016/j.plantsci.2015.05.003

Pan, Q., Chen, Y., Wang, Q., Yuan, F., Xing, S., Tian, Y., et al. (2010). Effect of plant growth regulators on the biosynthesis of vinblastine, vindoline and catharanthine in Catharanthus roseus. Plant Growth Regulation. 60, 133-141. doi:10.1007/s10725-009-9429-1

Pandey, S., Ranade, S. A., Nagar, P. K. and Kumar, N. (2000). Role of polyamines and ethylene as modulators of plant senescence. J. Biosci. (Bangalore). 25, 291-299. doi:10.1007/bf02703938

Qin, L., Zhang, X., Yan, J., Fan, L., Rong, C. X., Mo, C. Y., et al. (2019). Effect of exogenous spermidine on floral induction, endogenous polyamine and hormone production, and expression of related genes in 'Fuji' apple (Malys domestica Borkh.). Scientific Reports. 9. doi:10.1038/s41598-019-49280-0

Rey, M., Díaz-Sala, C. and Rodríguez, R. (2006). Comparison of endogenous polyamine content in hazel leaves and buds between the annual dormancy and flowering phases of growth. Physiol. Plant. 91, 45-50. doi:10.1111/j.1399-3054.1994.tb00657.x

Risa, D., Pacifici, S. and Burchi, G. (2018). Tepal senescence and tepal abscission in brindisi Lily flowers: possible role of hormones other than ethylene. Journal of Interdisciplinary biosciences. 2, 21-28. doi:10.29336/JIBS/171201/180401

Roubelakis-Angelakis, K. A. (2009). Plant polyamine catabolism: The state of the art. Plant Signaling \& Behavior. 3, 1061-1066. doi:10.4161/psb.3.12.7172

Sabehat, A. and Zieslin, N. (1994). GA3 Effects on Postharvest Alterations in Cell Membranes of Rose (Rosa x Hybrida) Petals. J. Plant Physiol. 144, 513-517. doi:10.1016/S0176-1617(11)82131-0

Saftner, R. A. , Baldi, B. G. (1990). Polyamine Levels and Tomato Fruit Development: Possible Interaction with Ethylene. Plant Physiology. 92(2):547-550. doi: 10.1104/pp.92.2.547

Saks, Y. and Staden, J. (1993). Evidence for the involvement of gibberellins in developmental phenomena associated with carnation flower senescence. Plant Growth Regulation. 12, 105-110. doi:10.1007/bf00144590

Sequera-Mutiozabal, M. I., Erban, A., Kopka, J., Atanasov, K. E., Bastida, J., Fotopoulos, V., et al. (2016). Global Metabolic Profiling of Arabidopsis Polyamine Oxidase 4 (AtPAO4) Loss-of-Function Mutants Exhibiting Delayed Dark-Induced Senescence. Frontiers in plant science. 7. doi:10.3389/fpls.2016.00173 
Sheikh, M. S. and Farooq, S. (1999). Effect of sucrose and GA3 on the senescence of cut flowers of Narcissus tazetta cv. Kashmir Local. Advances in Horticultural Science 13, 105-107

Silva, G. F. F., Silva, E. M., Correa, J. P. O., Vicente, M. H., Jiang, N., Notini, M. M., et al. (2019). Tomato floral induction and flower development are orchestrated by the interplay between gibberellin and two unrelated microRNA-controlled modules. New Phytol. 221, 1328-1344. doi:10.1111/nph.15492

Simões, A. N., Bandeiradiniz, N., Vieira, M. R. S., Luizferreira-Silva, S., Silva, M. B., Otaviominatel, I., et al. (2018). Impact of $\mathrm{GA}_{3}$ and spermine on postharvest quality of anthurium cut flowers (Anthurium andraeanum) cv. Arizona. Scientia Horticulturae. 241, 178-186. doi:10.1016/j.scienta.2018.06.095

Sobieszczuk-Nowicka, E. (2016). Polyamine catabolism adds fuel to leaf senescence. Amino Acids. 49, 49-56. doi:10.1007/s00726-016-2377-y

Sood, S. and Nagar, P. K. (2004). Changes in endogenous polyamines during flower development in two diverse species of rose. Plant Growth Regulation. 44, 117-123

Sorkheh, K., Shiran, B., Rouhi, V., Khodambashi, M., Wolukau, J. N. and Ercisli, S. (2011). Response of in vitro pollen germination and pollen tube growth of almond (Prunus dulcis Mill.) to temperature, polyamines and polyamine synthesis inhibitor. Biochemical Systematics \& Ecology. 39, 749-757. doi:10.1016/j.bse.2011.06.015

Srikanth, A. and Schmid, M. (2011). Regulation of flowering time: all roads lead to Rome. Cell. Mol. Life Sci. 68, 2013-2037. doi:10.1007/s00018-011-0673-y

Su, G., An, Z., Zhang, W. and Liu, Y. (2006). Light promotes the synthesis of lignin through the production of $\mathrm{H} 2 \mathrm{O} 2$ mediated by diamine oxidases in soybean hypocotyls. J. Plant Physiol. 162, 1297-1303. doi:10.1016/j.jplph.2005.04.033

Takano, A., Kakehi, J. I. and Takahashi, T. (2012). Thermospermine is Not a Minor Polyamine in the Plant Kingdom. Plant and Cell Physiology. 53, 606-616. doi:10.1093/pcp/pcs019

Tatte, A. S. and Ahlawat, T. (2015). Effect of polyamines on postharvest quality and vaselife of rose var. Samurai. The Bioscan. 10, 675-678

Tiburcio, A. F., Kaur-Sawhney, R. and Galston, A. W. (1988). Polyamine Biosynthesis during Vegetative and Floral Bud Differentiation in Thin Layer Tobacco Tissue Cultures. Plant Cell Physiol. 29, 1241-1249. doi:10.1093/oxfordjournals.pcp.a077629

Van Doorn, W. G. and Woltering, E. J. (2008). Physiology and molecular biology of petal senescence. J. Exp. Bot. 59, 453-480

Wada, N., Shinozaki, M. and Iwamura, H. (1994). Flower Induction by Polyamines and Related Compounds in Seedlings of Morning Glory (Pharbitis nil cv. Kidachi). Plant Cell Physiol. 35, 469-472. 
Wang, S. Z., Li, Z. L., Jin, W. B., Fang, Y. P., Yang, Q. F. and Xiang, J. (2018). Transcriptome analysis and identification of genes associated with flower development in Rhododendron pulchrum Sweet (Ericaceae). Gene. 679, 108-118. doi:10.1016/j.gene.2018.08.083

Wang, W., Paschalidis, K., Feng, J. C., Song, J. and Liu, J. H. (2019). Polyamine Catabolism in Plants: A Universal Process With Diverse Functions. Frontiers in plant science. 10. doi:10.3389/fpls.2019.00561

Wimalasekera, R., Tebartz, F. and Scherer, G. F. (2011). Polyamines, polyamine oxidases and nitric oxide in development, abiotic and biotic stresses. Plant Science An International Journal of Experimental Plant Biology. 181, 593-603. doi:10.1016/j.plantsci.2011.04.002

Yoda, H., Hiroi, Y. and Sano, H. (2006). Polyamine Oxidase Is One of the Key Elements for Oxidative Burst to Induce Programmed Cell Death in Tobacco Cultured Cells. Plant Physiol. 142, 193-206. doi:10.1104/pp.106.080515

Yu, F. Y., Groen, T. A., Wang, T. J., Skidmore, A. K., Huang, J. H. and Ma, K. P. (2017). Climatic niche breadth can explain variation in geographical range size of alpine and subalpine plants. International Journal of Geographical Information Science. 31, 190-212. doi:10.1080/13658816.2016.1195502

Yu, Z., Jia, D. and Liu, T. (2019). Polyamine Oxidases Play Various Roles in Plant Development and Abiotic Stress Tolerance. Plants-Basel. 8. doi:10.3390/plants8060184

Zhang, H. and Zhou, C. (2013). Signal transduction in leaf senescence. Plant Mol. Biol. 82, 539-545. doi:10.1007/s11103-012-9980-4

Zhao, F. G., Sun, C., Liu, Y. L. and Zhang, W. H. (2003). Relationship between polyamine metabolism in roots and salt tolerance of barley seedlings. Acta Botanica Sinica. 45, 295-300

Zhao, J., Qiu, S., Xiu-Juan, L. I. and Zhang, C. P. (2009). Effects of different plant hormones on flower induction of Rhododendron pulchrum. Guihaia. doi:10.1016/j.marpolbul.2013.06.035

Ahmed S, Ariyaratne M, Patel J, Howard AE, Kalinoski A, Phuntumart V, Morris PF (2017) Altered expression of polyamine transporters reveals a role for spermidine in the timing of flowering and other developmental response pathways Plant Science 258:146-155 doi:10.1016/j.plantsci.2016.12.002

Ahou A et al. (2014) A plant spermine oxidase/dehydrogenase regulated by the proteasome and polyamines Journal of Experimental Botany 65:1585-1603 doi:10.1093/jxb/eru016

Alcázar R, Cuevas JC, Tiburcio AF, Altabella T (2005) Overexpression of ADC2 in Arabidopsis induces dwarfism and late-flowering through GA deficiency Plant J 43:425-436 doi:doi:10.1111/j.1365-

313X.2005.02465.X 
Altamura MM, Torrigiani P, Falasca G, Rossini P, Bagni N (1993) Morpho-funcional Gradients in Superficial and Deep Tissues along Tobacco Stem: Polyamine Levels, Biosynthesis and Oxidation, and Organogenesis in vitro J Plant Physiol 142:543-551 doi:10.1016/S0176-1617(11)80396-2

Angelini R, Cona A, Federico R, Fincato P, Tavladoraki P, Tisi A (2010) Plant amine oxidases "on the move": An update Plant Physiology \& Biochemistry Ppb 48:560-564 doi:10.1016/j.plaphy.2010.02.001

Applewhite PB, Kaur-Sawhney R, Galston AW (2010) A role for spermidine in the bolting and flowering of Arabidopsis Physiologia Plantarum 108:314-320 doi:10.1034/j.1399-3054.2000.108003314.x

Aribaud M, Kevers C, Martin-Tanguy J, Gaspar T (1998) Low activity of amine-oxidases and accumulation of conjugated polyamines in disfavour of organogenic programs in Chrysanthemum leaf disc explants Plant Cell Tissue \& Organ Culture 55:85-94 doi:doi: 10.1023/A:1006153806610

Bagni N, Tassoni A (2001) Biosynthesis, oxidation and conjugation of aliphatic polyamines in higher plants Amino Acids 20:301-317 doi:10.1007/s007260170046

Bagni N, Tassoni A (2006) The role of polyamines in relation to flower senescence Floriculture Ornamental \& Plant Biotechnology 1536:855-856

Baron K, Stasolla C (2008) The role of polyamines during in vivo and in vitro development In Vitro Cellular \& Developmental Biology-Plant 44:384-395 doi:10.1007/s11627-008-9176-4

Berta G, Altamura MM, Fusconi A, Cerruti F, Capitani F, Bagni N (2010) The plant cell wall is altered by inhibition of polyamine biosynthesis New Phytologist 137:569-577 doi:10.1046/j.1469-

8137.1997.00868.x

Cai G, Della Mea M, Faleri C, Fattorini L, Aloisi I, Serafini-Fracassini D, Del Duca S (2015a) Spermine either delays or promotes cell death in Nicotiana tabacum L. corolla depending on the floral developmental stage and affects the distribution of transglutaminase Plant Science 241:11-22 doi:10.1016/j.plantsci.2015.09.023

Cai G, Sobieszczuk-Nowicka E, Aloisi I, Fattorini L, Serafini-Fracassini D, Del Duca S (2015b) Polyamines are common players in different facets of plant programmed cell death Amino Acids 47:27-44 doi:10.1007/s00726-014-1865-1

Carbonell J, Blazquez MA (2009) Regulatory Mechanisms of Polyamine Biosynthesis in Plants Genes \& Genomics 31:107-118 doi:10.1007/bf03191144

Chang YS, Sung FH (2000) Effects of gibberellic acid and dormancy-breaking chemicals on flower development of Rhododendron pulchrum Sweet and R. scabrum Don Scientia Horticulturae 83:331-337 doi:10.1016/S0304-4238(99)00111-9 
Chen DD, Shao QS, Yin LH, Younis A, Zheng BS (2019) Polyamine Function in Plants: Metabolism, Regulation on Development, and Roles in Abiotic Stress Responses Frontiers in Plant Science 9 doi:10.3389/fpls.2018.01945

Chen TT, Xu YJ, Wang JC, Wang ZQ, Yang JC, Zhang JH (2013) Polyamines and ethylene interact in rice grains in response to soil drying during grain filling Journal of Experimental Botany 64:2523-2538 doi:10.1093/jxb/ert115

Choudhary S, Thakur S, Jaitak V, Bhardwaj P (2019) Gene and metabolite profiling reveals flowering and survival strategies in Himalayan Rhododendron arboreum Gene 690:1-10 doi:10.1016/j.gene.2018.12.035

Del Duca S, Serafini-Fracassini D, Cai G (2014) Senescence and programmed cell death in plants: polyamine action mediated by transglutaminase Frontiers in Plant Science 5 doi:10.3389/fpls.2014.00120

Domenico P (2018) TEPAL SENESCENCE AND TEPAL ABSCISSION IN BRINDISI LILY FLOWERS: POSSIBLE ROLE OF HORMONES OTHER THAN ETHYLENE

Domingos S, Fino J, Paulo OS, Oliveira CM, Goulao LF (2016) Molecular candidates for early-stage flowerto-fruit transition in stenospermocarpic table grape (Vitis vinifera L.) inflorescences ascribed by differential transcriptome and metabolome profiles Plant Science 244:40-56 doi:10.1016/j.plantsci.2015.12.009

Doncaster CP (2007) Structural Equation Modeling and Natural Systems Fish \& Fisheries 8:368-369 doi:10.1111/j.1467-2979.2007.00260.x

Dong-Hua XU, Guo JE, Lu XU, Sun X, Sun XZ (2014) The Relationship Between Polyamine Oxidase Activity and Lignin Deposition and Chrysanthemum Flower Bud Differentiation Acta Agriculturae BorealiSinica

Duan HG (2006) The Role of Polyamines in the Ontogeny of Higher Plants Acta Agriculturae BorealiOccidentalis Sinica

Eason, R. J (2002) An evaluation of postharvest pulsing solutions to maximise cut flower quality New Zealand Journal of Crop \& Horticultural Science 30:273-279 doi:10.1080/01140671.2002.9514224

Evans PT, Malmberg R (1989) Do Polyamines Have Roles in Plant Development? Annurevplant Physiolplant Molbiol 40:235-269 doi:10.1146/annurev.pp.40.060189.001315

Fortes AM, Agudelo-Romero P (2018) Polyamine Metabolism in Climacteric and Non-Climacteric Fruit Ripening vol 1964. doi:10.1007/978-1-4939-7398-9_36

Handa AK, Mattoo A (2010a) Differential and functional interactions emphasize the multiple roles of polyamines in plants Plant Physiology and Biochemistry 48:540-546 doi:10.1016/j.plaphy.2010.02.009 
Handa AK, Mattoo AK (2010b) Differential and functional interactions emphasize the multiple roles of polyamines in plants Plant Physiology and Biochemistry 48:540-546 doi:10.1016/j.plaphy.2010.02.009

Havelange A, Lejeune P, Bernier G, Kaur-Sawhney R, Galston AW (1996) Putrescine export from leaves in relation to floral transition in Sinapis alba Physiologia Plantarum 96:59-65 doi:10.1111/j.13993054.1996.tb00183.x

He Y et al. (2004) Nitric oxide represses the Arabidopsis floral transition Science 305:1968-1971 doi:10.1126/science.1098837

Hu XH, Zhang Y, Shi Y, Zhang Z, Zou ZR, Zhang H, Zhao JZ (2012) Effect of exogenous spermidine on polyamine content and metabolism in tomato exposed to salinity-alkalinity mixed stress Plant Physiology and Biochemistry 57:200-209 doi:10.1016/j.plaphy.2012.05.015

Huang CK et al. (2004) Changes in polyamine pattern are involved in floral initiation and development in Polianthes tuberosa Journal of Plant Physiology 161:709-713 doi:10.1078/0176-1617-01256

Huang YT, Lin C, He F, Li Z, Guan YJ, Hu QJ, Hu J (2017) Exogenous spermidine improves seed germination of sweet corn via involvement in phytohormone interactions, $\mathrm{H} 2 \mathrm{O} 2$ and relevant gene expression Bmc Plant Biology 17 doi:10.1186/s12870-016-0951-9

Hummel I, Couée I, Amrani AE, Martin-Tanguy J, Hennion F (2002) Involvement of polyamines in root development at low temperature in the subantarctic cruciferous species Pringlea antiscorbutica Journal of Experimental Botany 53:1463-1473 doi:10.1093/jexbot/53.373.1463

Kaur-Sawhney et al. (2003) Polyamines in plants: An overview Journal of Cell \& Molecular Biology 2:1-12 Kaur-Sawhney R, Flores HE, Galston AW (1980) Polyamine-Induced DNA Synthesis and Mitosis in Oat Leaf Protoplasts Plant Physiology 65:368-371 doi:10.1104/pp.65.2.368

Lee MM, Lee SH, Park KY (1997) Effects of spermine on ethylene biosynthesis in cut carnation (Dianthus caryophyllus L) flowers during senescence Journal of Plant Physiology 151:68-73 doi:10.1016/S01761617(97)80038-7

Li LJ et al. (2018) Exogenously applied spermidine alleviates photosynthetic inhibition under drought stress in maize (Zea mays L.) seedlings associated with changes in endogenous polyamines and phytohormones Plant Physiology and Biochemistry 129:35-55 doi:10.1016/j.plaphy.2018.05.017

Lu PT et al. (2014) RhHB1 mediates the antagonism of gibberellins to ABA and ethylene during rose ( Rosa hybrida) petal senescence Plant Journal 78:578-590 doi:10.1111/tpj.12494

Majumdar R, Barchi B, Turlapati SA, Gagne M, Minocha R, Long S, Minocha SC (2016) Glutamate, Ornithine, Arginine, Proline, and Polyamine Metabolic Interactions: The Pathway Is Regulated at the PostTranscriptional Level Frontiers in Plant Science 7 doi:10.3389/fpls.2016.00078 
Malmberg RL, Mcindoo J (1983) Abnormal floral development of a tobacco mutant with elevated polyamine levels 305:623-625 doi:10.1038/305623a0

Masson PH, Takahashi T, Angelini R (2017) Editorial: Molecular Mechanisms Underlying Polyamine Functions in Plants Frontiers in Plant Science 8 doi:10.3389/fpls.2017.00014

Matsoukas IG, Massiah AJ, Thomas B (2012) Florigenic and Antiflorigenic Signaling in Plants Plant and Cell Physiology 53:1827-1842 doi:10.1093/pcp/pcs130

Mehta RA, Cassol T, Li N, Ali N, Handa AK, Mattoo AK (2002) Engineered polyamine accumulation in tomato enhances phytonutrient content, juice quality, and vine life Nature Biotechnology 20:613-618 doi:10.1038/nbt0602-613

Meijon M, Canal MJ, Fernandez H, Rodriguez A, Fernandez B, Rodriguez R, Feito I (2011) Hormonal Profile in Vegetative and Floral Buds of Azalea: Levels of Polyamines, Gibberellins, and Cytokinins Journal of Plant Growth Regulation 30:74-82 doi:10.1007/s00344-010-9169-5

Molesini B, Mennella G, Martini F, Francese G, Pandolfini T (2015) Involvement of the Putative NAcetylornithine Deacetylase from Arabidopsis thaliana in Flowering and Fruit Development Plant and Cell Physiology 56:1084-1096 doi:10.1093/pcp/pcv030

Moschou PN, Paschalidis KA, Roubelakis-Angelakis KA (2008) Plant polyamine catabolism: The state of the art Plant signaling \& behavior 3:1061-1066 doi:10.4161/psb.3.12.7172

Mutasa-Gottgens E, Hedden P (2009) Gibberellin as a factor in floral regulatory networks Journal of Experimental Botany 60:1979-1989 doi:10.1093/jxb/erp040

Nambeesan SU, Mattoo AK, Handa AK (2019) Nexus Between Spermidine and Floral Organ Identity and Fruit/Seed Set in Tomato Frontiers in Plant Science 10 doi:10.3389/fpls.2019.01033

Naseri S, Gholami M, Baninasab B (2019) Changes in polyamines during bud dormancy in almond cultivars differing in their flowering date Scientia Horticulturae 258 doi:10.1016/j.scienta.2019.108788

Nölke G, Schneider B, Fischer R, Schillberg S (2010) Immunomodulation of polyamine biosynthesis in tobacco plants has a significant impact on polyamine levels and generates a dwarf phenotype Plant Biotechnology Journal 3:237-247 doi:10.1111/j.1467-7652.2005.00121.x

Pal M, Szalai G, Janda T (2015) Speculation: Polyamines are important in abiotic stress signaling Plant Science 237:16-23 doi:10.1016/j.plantsci.2015.05.003

Pan QF et al. (2010) Effect of plant growth regulators on the biosynthesis of vinblastine, vindoline and catharanthine in Catharanthus roseus Plant Growth Regulation 60:133-141 doi:10.1007/s10725-0099429-1 
Pandey S, Ranade SA, Nagar PK, Kumar N (2000) Role of polyamines and ethylene as modulators of plant senescence J Biosci 25:291-299 doi:10.1007/bf02703938

Qin L, Zhang X, Yan J, Fan L, Rong CX, Mo CY, Zhang MR (2019) Effect of exogenous spermidine on floral induction, endogenous polyamine and hormone production, and expression of related genes in 'Fuji' apple (Malys domestica Borkh.) Scientific Reports 9 doi:10.1038/s41598-019-49280-0

Rey M, Díaz-Sala C, Rodríguez R (1994) Comparison of endogenous polyamine content in hazel leaves and buds between the annual dormancy and flowering phases of growth Physiologia Plantarum 91:45-50 doi:10.1111/j.1399-3054.1994.tb00657.x

Sabehat A, Zieslin N (1994) GA3 Effects on Postharvest Alterations in Cell Membranes of Rose (Rosa $\mathrm{x}$ Hybrida) Petals Journal of Plant Physiology 144:513-517 doi:10.1016/S0176-1617(11)82131-0

Saftner RA, Baldi BG (1990) Polyamine Levels and Tomato Fruit Development: Possible Interaction with Ethylene Plant Physiology 92:547-550 doi:10.1104/pp.92.2.547

Saks Y, Staden J (1993) Evidence for the involvement of gibberellins in developmental phenomena associated with carnation flower senescence Plant Growth Regulation 12:105-110 doi:10.1007/bf00144590

Sequera-Mutiozabal MI et al. (2016) Global Metabolic Profiling of Arabidopsis Polyamine Oxidase 4 (AtPA04) Loss-of-Function Mutants Exhibiting Delayed Dark-Induced Senescence Frontiers in Plant Science 7 doi:10.3389/fpls.2016.00173

Sheikh MS, Farooq S (1999) Effect of sucrose and GA3 on the senescence of cut flowers of Narcissus tazetta cv. Kashmir Local Advances in Horticultural Science 13:105-107

Silva GFF et al. (2019) Tomato floral induction and flower development are orchestrated by the interplay between gibberellin and two unrelated microRNA-controlled modules New Phytologist 221:1328-1344 doi:10.1111/nph.15492

Simões ADN, Diniz NB, Vieira MRdS, Ferreira-Silva SL, Silva MBd, Minatel IO, Lima G (2018) Impact of GA3 and spermine on postharvest quality of anthurium cut flowers (Anthurium andraeanum ) cv. Arizona Scientia Horticulturae 241:178-186 doi:10.1016/j.scienta.2018.06.095

Sobieszczuk-Nowicka E (2017) Polyamine catabolism adds fuel to leaf senescence Amino Acids 49:4956 doi:10.1007/s00726-016-2377-y

Sood S, Nagar PK (2004) Changes in endogenous polyamines during flower development in two diverse species of rose* Plant Growth Regulation 44:117-123

Sorkheh K, Shiran B, Rouhi V, Khodambashi M, Wolukau JN, Ercisli S (2011) Response of in vitro pollen germination and pollen tube growth of almond (Prunus dulcis Mill.) to temperature, polyamines and 
polyamine synthesis inhibitor Biochemical Systematics and Ecology 39:749-757 doi:10.1016/j.bse.2011.06.015

Srikanth A, Schmid M (2011) Regulation of flowering time: all roads lead to Rome Cellular and Molecular Life Sciences 68:2013-2037 doi:10.1007/s00018-011-0673-y

Su G, An Z, Zhang W, Liu Y (2005) Light promotes the synthesis of lignin through the production of H2O2 mediated by diamine oxidases in soybean hypocotyls Journal of Plant Physiology 162:1297-1303 doi:10.1016/j.jplph.2005.04.033

Sven Eriksson HB, Thomas Moritz, Nilsson O (2006) GA4 Is the Active Gibberellin in the Regulation of LEAFY Transcription and Arabidopsis Floral Initiation[W] The Plant cell 18:2172-2181 doi:10.1105/tpc.106.042317

Takahashi T (2012) Thermospermine is Not a Minor Polyamine in the Plant Kingdom Plant \& Cell Physiology 53:606-616 doi:10.1093/pcp/pcs019

Tatte AS, Ahlawat TR (2015) Effect of polyamines on postharvest quality and vaselife of rose var. Samurai The Bioscan 10:675-678

Tiburcio AF, Ravindar K-S, Galston AW (1988) Polyamine Biosynthesis during Vegetative and Floral Bud Differentiation in Thin Layer Tobacco Tissue Cultures Plant \& Cell Physiology 29:1241-1249 doi:10.1093/oxfordjournals.pcp.a077629

van Doorn WG, Woltering EJ (2008) Physiology and molecular biology of petal senescence Journal of Experimental Botany 59:453-480 doi:10.1093/jxb/erm356

Wada N, Shinozaki M, Iwamura H (1994) Flower Induction by Polyamines and Related Compounds in Seedlings of Morning Glory (Pharbitis nil cv. Kidachi) Plant \& Cell Physiology 35:469-472 doi:10.1093/oxfordjournals.pcp.a078617

Wang SZ, Li ZL, Jin WB, Fang YP, Yang QF, Xiang J (2018) Transcriptome analysis and identification of genes associated with flower development in Rhododendron pulchrum Sweet (Ericaceae) Gene 679:108118 doi:10.1016/j.gene.2018.08.083

Wang W, Paschalidis K, Feng JC, Song J, Liu JH (2019) Polyamine Catabolism in Plants: A Universal Process With Diverse Functions Frontiers in Plant Science 10 doi:10.3389/fpls.2019.00561

Wimalasekera R, Tebartz F, Scherer GFE (2011) Polyamines, polyamine oxidases and nitric oxide in development, abiotic and biotic stresses Plant Science 181:593-603 doi:10.1016/j.plantsci.2011.04.002

Yoda H, Hiroi Y, Sano H (2006) Polyamine Oxidase Is One of the Key Elements for Oxidative Burst to Induce Programmed Cell Death in Tobacco Cultured Cells Plant Physiology 142:193-206 doi:10.1104/pp.106.080515 
Yu FY, Groen TA, Wang TJ, Skidmore AK, Huang JH, Ma KP (2017) Climatic niche breadth can explain variation in geographical range size of alpine and subalpine plants International Journal of Geographical Information Science 31:190-212 doi:10.1080/13658816.2016.1195502

Yu Z, Jia DY, Liu TB (2019) Polyamine Oxidases Play Various Roles in Plant Development and Abiotic Stress Tolerance Plants-Basel 8 doi:10.3390/plants8060184

Zhang HS, Zhou CJ (2013) Signal transduction in leaf senescence Plant Molecular Biology 82:539-545 doi:10.1007/s11103-012-9980-4

Zhao FG, Sun C, Liu YL, Zhang WH (2003) Relationship Between Polyamine Metabolism in Roots and Salt Tolerance of Barley Seedlings Acta Botanica Sinica 45:295-300

Zhao J, Qiu S, Xiu-Juan LI, Zhang CP (2009) Effects of different plant hormones on flower induction of Rhododendron pulchrum Guihaia 74:320-324 doi:10.1016/j.marpolbul.2013.06.035

\section{Figures}
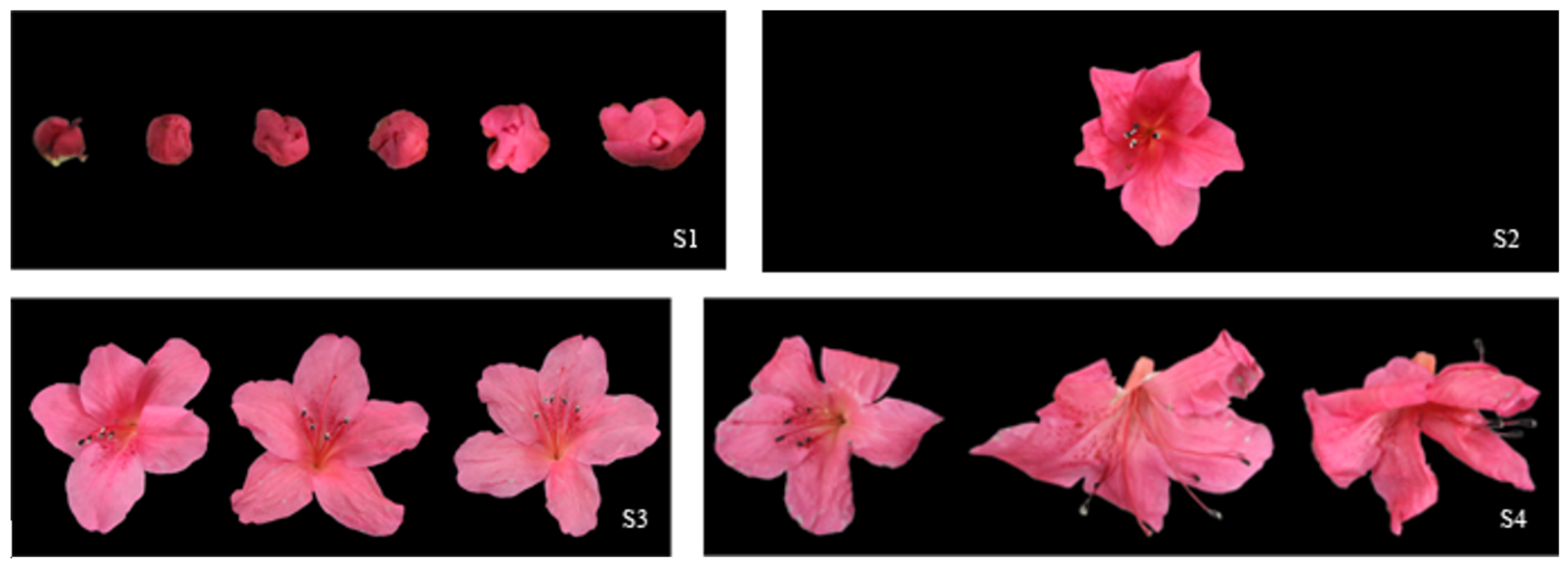

\section{Figure 1}

Four stages of the flowering period. The flower opening of Rhododendron was divided into four stages. During stage 1 , the squaring stage, $30 \%$ of buds display color, and most of them are tightly closed. During stage 2, the early flowering stage, there initially is a small number of flowers, most of which are still in a semiclosed state. Stage 3, the blooming stage, is characterized by more than $50 \%$ of open flowers and flowers presenting a deep color. During stage 4 , the end of flowering, the flower and flower stalk are easy to distinguish, the color is pale, and the flowers appear withered and scorched and begin to fall. The dates on which the plants entered the four stages were recorded. 

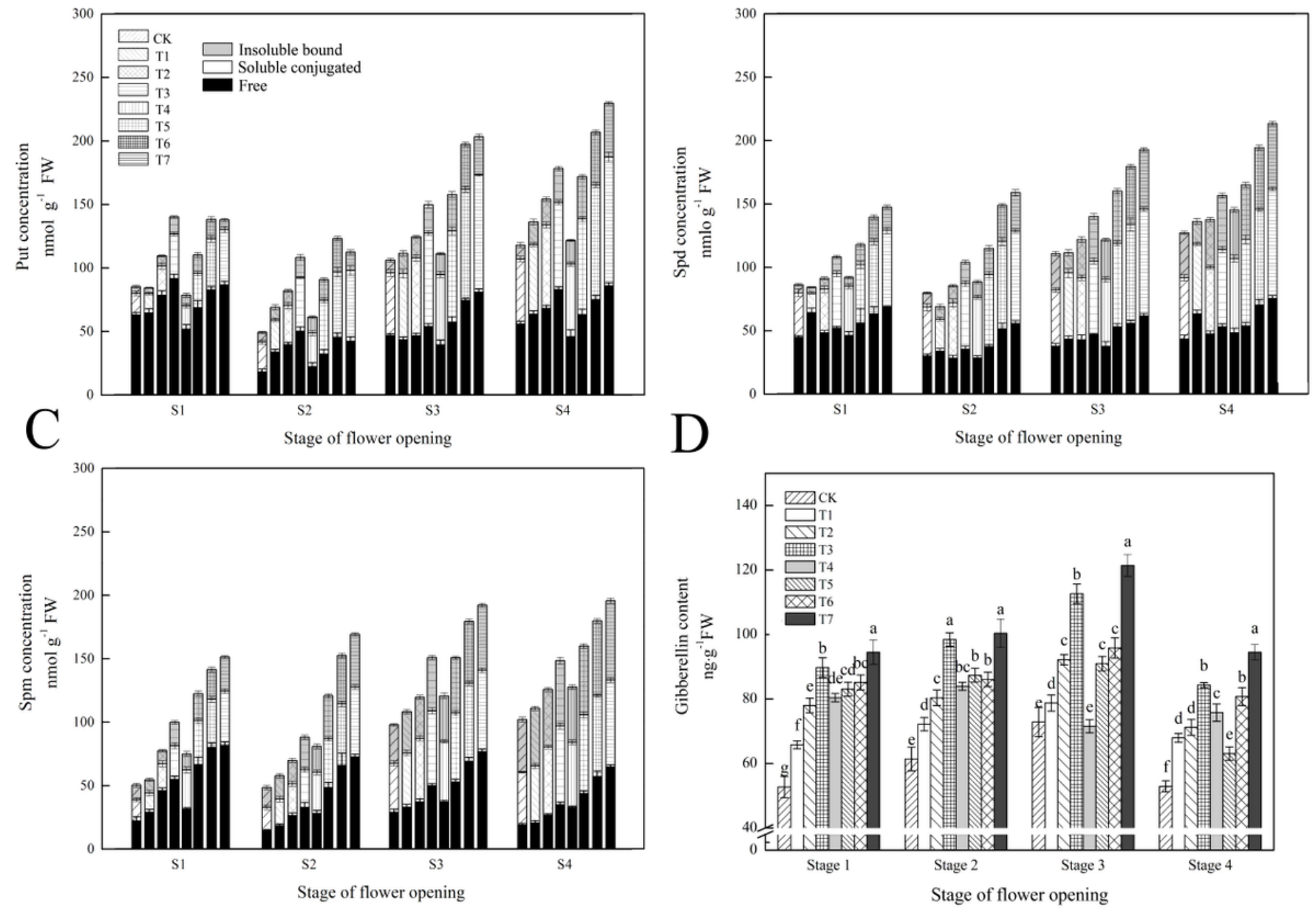

Figure 2

Effects of GA3 and Spd on the levels of Put (A), Spd (B) and Spm (C) with free, soluble conjugated and insoluble bound fractions and gibberellin (D) during the flowering process of petals of Rhododendron. Vertical bars represent the SDs of the mean $(n=3)$. Bars within each stage of flower opening in different treatments labeled by the same letters are not significantly different according to the Duncan's multiple test $(\mathrm{P}=0.05)$. 
A

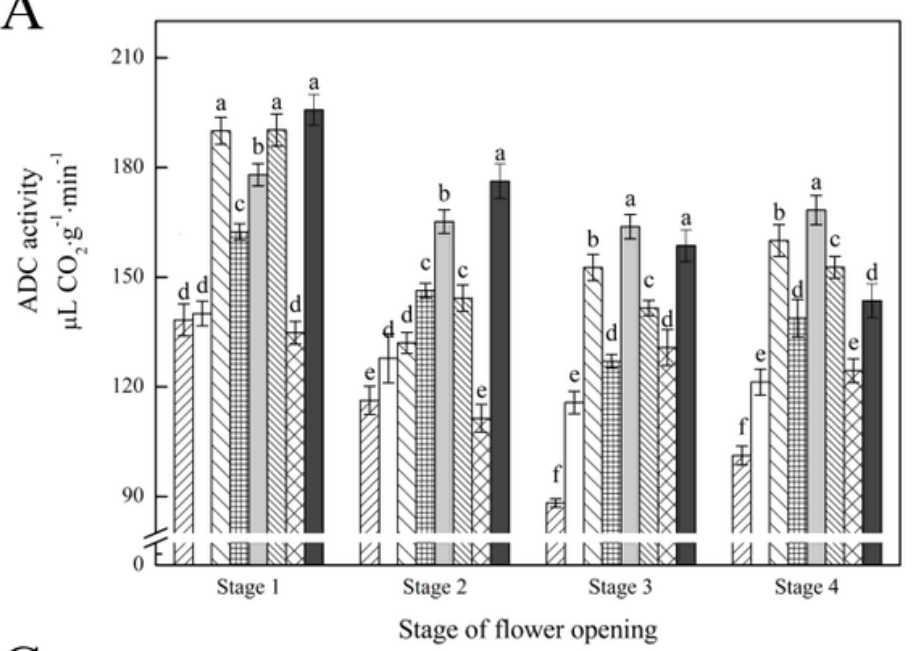

$\mathrm{C}$

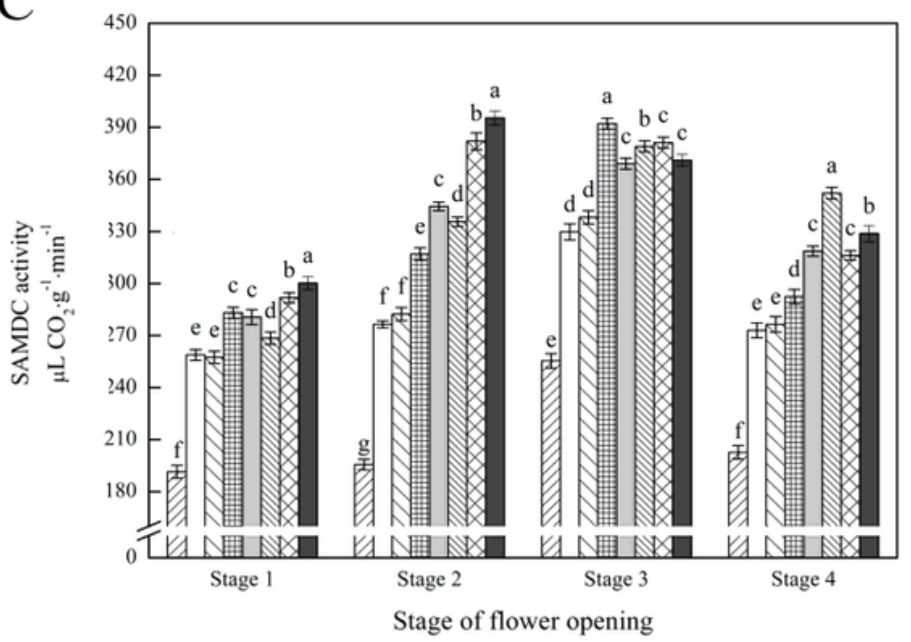

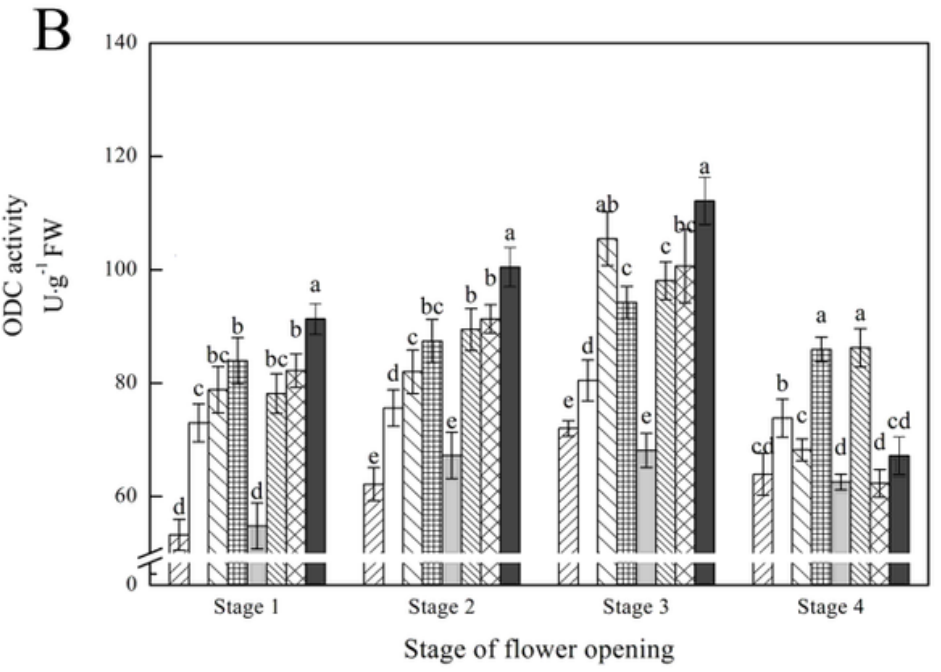

DIACK

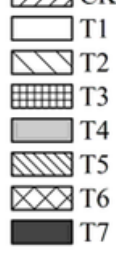

\section{Figure 3}

Effects of $G A 3$ and Spd on the activities of $A D C(A), O D C(B)$ and SAMDC(C) in Rhododendron petals during the flowering process. Vertical bars represent the SDs of the mean $(n=3)$. Bars within each stage of flower opening in different treatments labeled by the same letters are not significantly different according to the Duncan's multiple test $(P=0.05)$. 
A

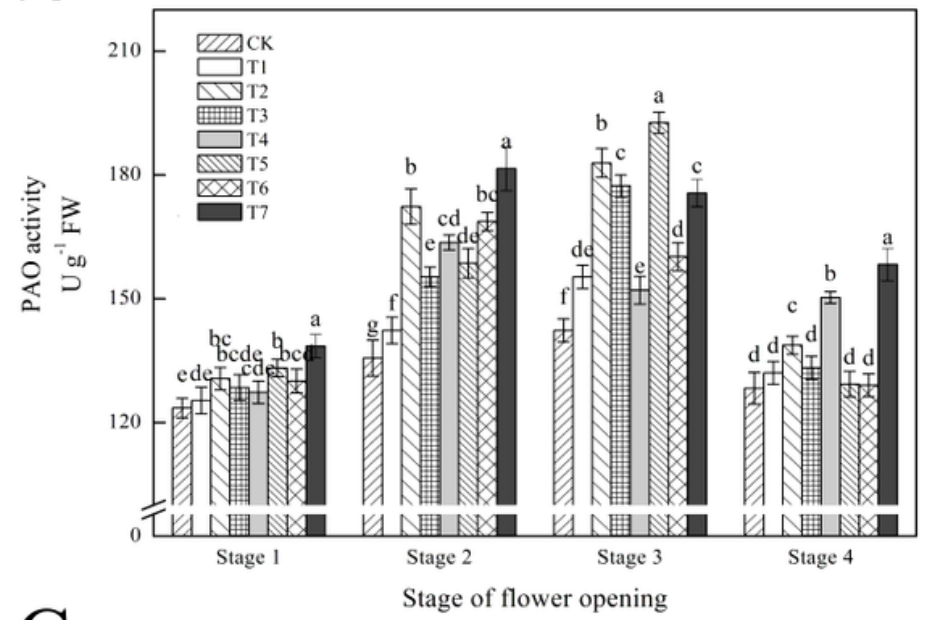

$\mathrm{C}$

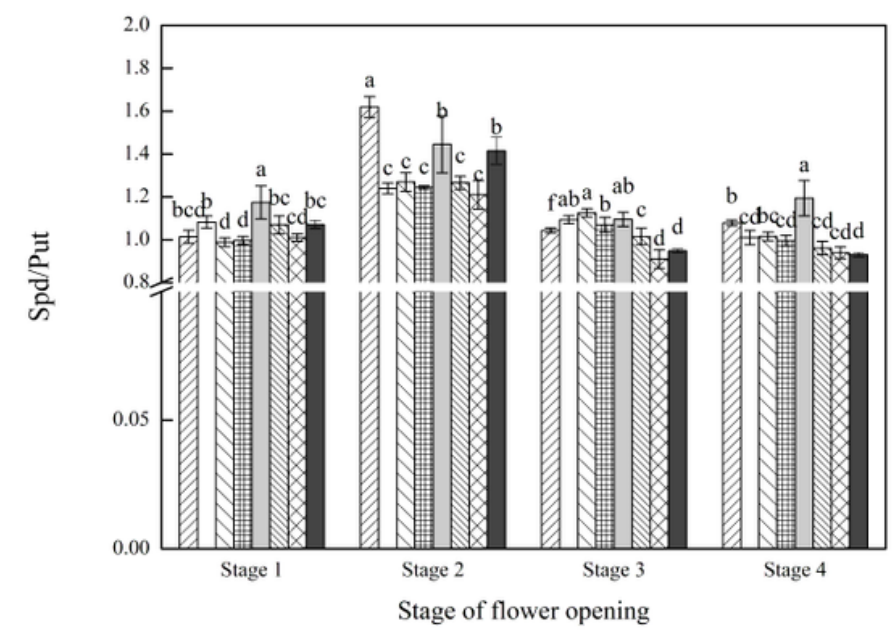

B

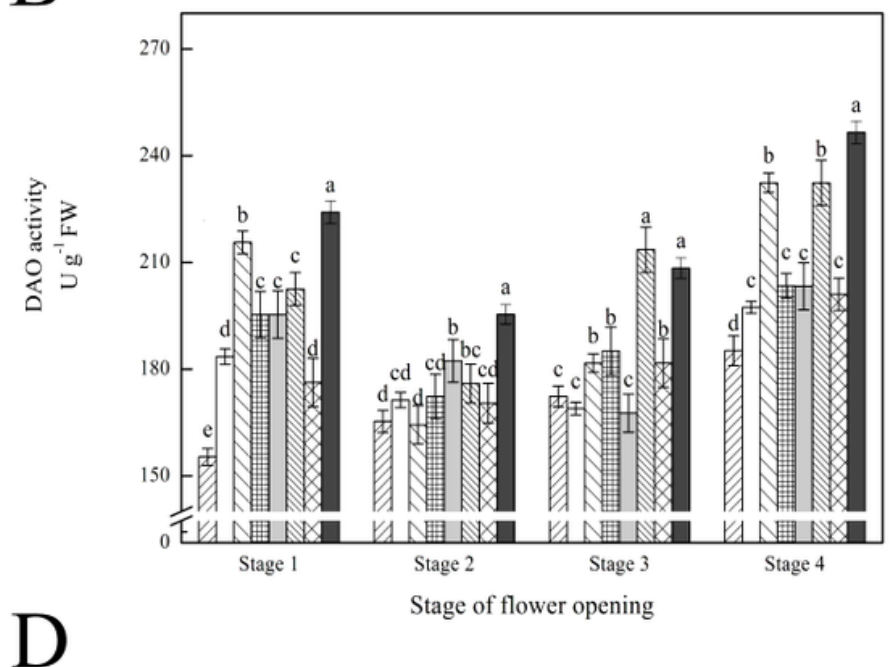

$\mathrm{D}$

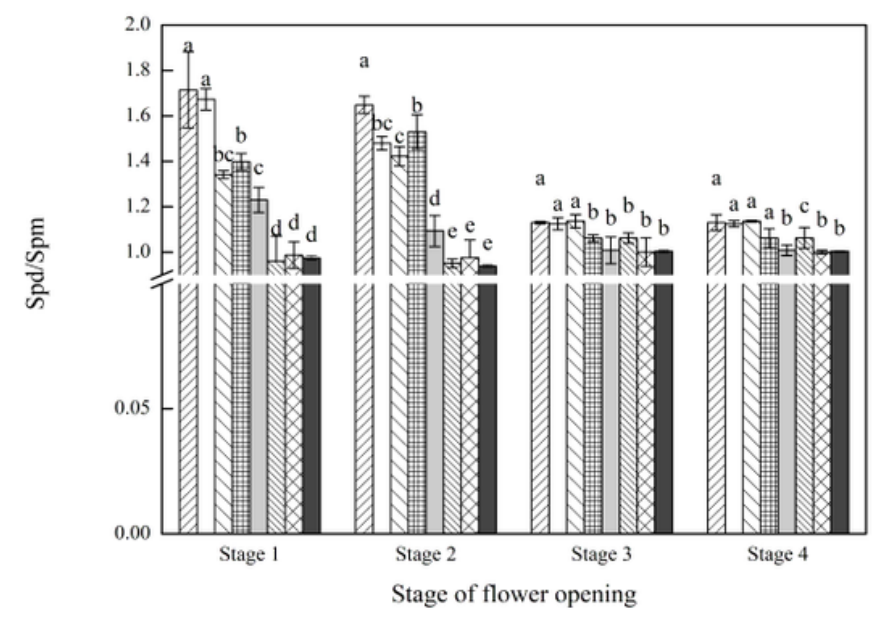

Figure 4

Effects of GA3 and Spd on the activities of DAO(A), PAO(B) and ratios of Spd/Put(C), Spd/Spm(D) in Rhododendron petals during the flowering process. Vertical bars represent the SDs of the mean $(n=3)$. Bars within each stage of flower opening in different treatments labeled by the same letters are not significantly different according to the Duncan's multiple test $(P=0.05)$. 


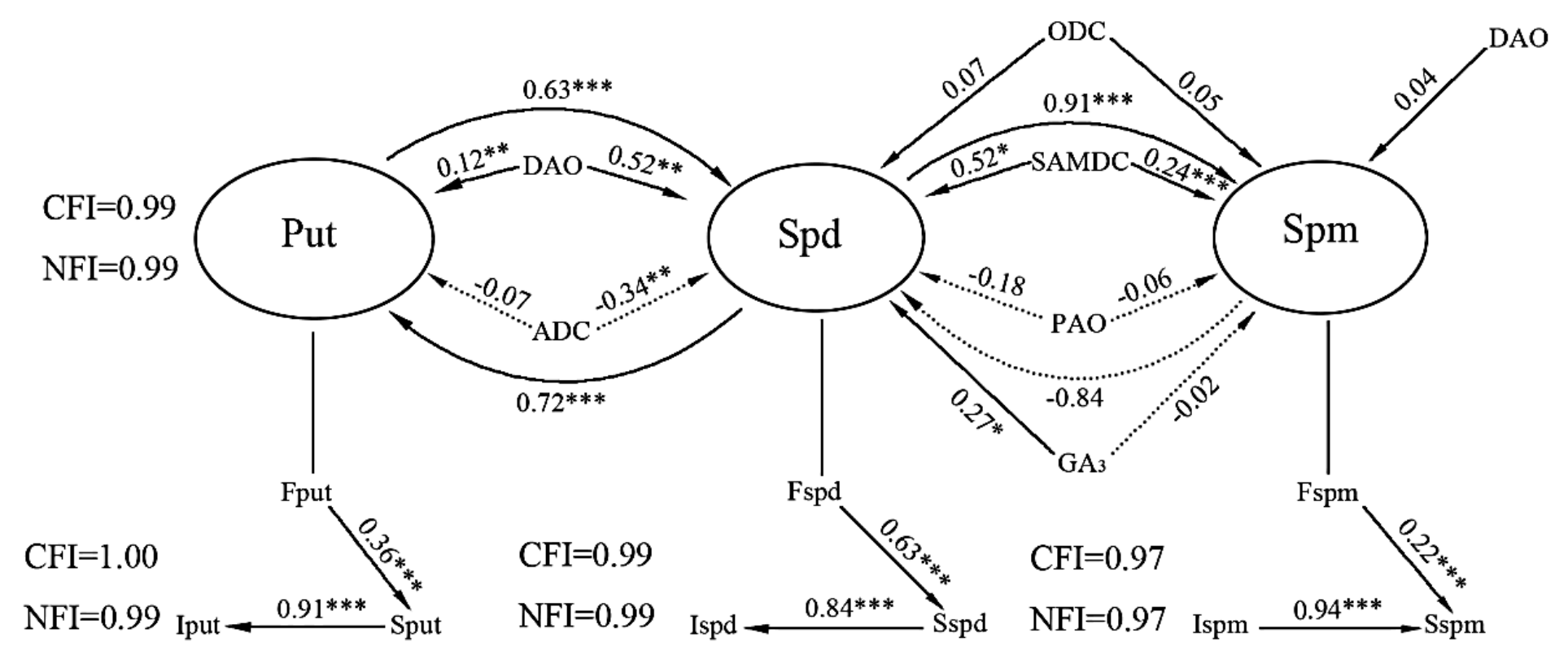

\section{Figure 5}

The SEM linking factors associated with PA metabolism in Rhododendron. Each arrow indicates a causal relationship; i.e., the change in the tail variable of the arrows are the direct cause of the change in the head variable. The solid and dashed lines show positive and negative paths, respectively. CFI and NFI are parameters that indicate model fitting. Standardized coefficients are listed on each path, and relatively large standard coefficients (listed next to each important path) indicate that the tail variables have a relatively strong effect on the head variables. * indicates a significant difference at the 0.05 level, ** indicates a significant difference at the 0.01 level, and $\star \star \star$ indicates a significant difference at the 0.001 level.

\section{Supplementary Files}

This is a list of supplementary files associated with this preprint. Click to download.

- Supplementaryfile.docx 